\title{
19. What Difference Does Government Make? Measuring Redistribution in a Comparative Perspective
}

\author{
Peter Whiteford
}

\section{Introduction}

Government policies in all countries affect the distribution of household income. In high-income countries, they do so through a range of programs but most directly through the cash transfers paid to households and the direct taxes and social security contributions collected from them. In addition, other social spending programs and other forms of taxes impact on households. Different welfare states may pursue a variety of social objectives, with the balance and priority given to each of them varying across both countries and between programs. A critical issue that all governments confront - particularly when considering policy reforms - is whether the redistributive and other policy objectives of society could be more effectively or efficiently achieved through a different mix or design of policies.

The appropriate level and structure of public spending and taxation is currently high on the policy agenda in Australia. The recent Grattan Institute report Budget pressures on Australian Governments (Daley, 2013) argued that Australian federal and state governments potentially face a combined annual deficit of around four per cent of GDP by 2023, of which around 2.5 per cent of GDP would be at the Commonwealth government level. In a subsequent address at the Per Capita think tank speech in late April the Prime Minister foreshadowed a reduction in projected tax revenues by the end of this financial year of around $\$ 12$ billion, leading to the need for 'urgent and grave Budget decisions'. In a speech to the Institute of Public Affairs in early May, the Shadow Treasurer, Joe Hockey said that 'attacking spending' and 'looking for structural saves' was increasingly urgent, and he referred to a speech given at the Institute of Economic Affairs in London in 2012 where he argued that 'all developed countries are now facing the end of the era of universal entitlement. Addressing the ongoing fiscal crises will involve the winding back of universal access to payments and entitlements from the state'.

It is interesting to note in this context that a recent OECD working paper (Rawdanowicz, Wurzel and Christensen, 2013) on 'The Equity Implications of 
Fiscal Consolidation' found that a cut in transfer spending of three per cent of GDP would increase income inequality in Australia to a larger extent than any other OECD country. As discussed below, the reason is that Australia has the most target-efficient transfer system in the OECD, so that a cut back of this magnitude would very adversely impact low-income groups.

This suggests that in deciding which policy directions to follow to bridge the budget gap, it is necessary to have a clear understanding of the distribution of welfare state spending, as well as how spending is financed. Australia is well placed in relation to information on the distributional impacts of government spending and taxing, notably because of the work of Ian Castles and others at the Australian Bureau of Statistics (ABS).

In March 1987, the ABS released The Effects of Government Benefits and Taxes on Household Income (ABS Catalogue No. 6537.0), which presented the results of a study of the effects of government benefits and taxes on the distribution of income of households in 1984, based primarily on data collected in the 1984 Household Expenditure Survey, supplemented by relevant data from other sources. Subsequently in May 1987 the then Social Welfare Research Centre at the University of New South Wales held a workshop on the study at which Ian Castles presented a paper on 'The Effects of Government Benefits and Taxes on Household Incomes: Estimates for Australia and Other Countries' (Saunders, 1987). As noted by Saunders (1987) this paper provided a stimulating and welcome addition to the literature on the effects of government benefits and taxes on the distribution of income in modern economies. The paper also illustrated the important lessons to be learnt from comparisons between countries with different social policy environments.

The Australian Bureau of Statistics subsequently published further studies using data from the Household Expenditure Surveys for 1988-89, 1993-94, 1998-99, 2003-05 and 2009-10 (Catalogue No. 6537.0).

Ian Castles and the ABS also contributed to improvements in international statistics in this area. An International Expert Group on Household Income Statistics, known as the 'Canberra Group', was established in 1996 at the initiative of the ABS in response to a growing awareness of the need to address the common conceptual, definitional and practical problems that national statistical offices face in the area of household income distribution statistics.

The primary objective of the Canberra Group was to enhance national household income statistics by developing relevant standards on conceptual and practical issues. To improve international comparability, the group developed and recommended international guidelines and standards. The Final Report of the Canberra Group was published in 2001. 
The Canberra Group Handbook on Household Income Statistics, Second Edition was published in 2011 by the United Nations Economic Commission for Europe. The updated volume provides a consolidated reference for those involved in producing, disseminating or analysing income distribution statistics. It reflects current international standards, recommendations and best practice in household income measurement. It also contains updated and expanded information about country practices in the field of statistics and provides guidance on best practices for quality assurance and dissemination of these statistics.

The second edition of the Handbook was prepared by a small international task force of experts from national statistical offices and international agencies, under the endorsement of the Bureau of the Conference of European Statisticians. The ABS played a leading role in the update, filling both the chair and editor roles for the task force.

The work of the Canberra Group is also reflected in changes that the ABS has made over the years to its series of income surveys. The ABS has conducted household income surveys since the late 1960s, although it is only surveys since 1982 that are comprehensive and available for public analysis. There have been major changes in methodology over the years, giving rise to a diversity of estimates of inequality. While changes have been made on a regular basis, recent changes are most significant. In 2007-08 the ABS revised its standards for household income statistics following the adoption of new international standards, which followed in turn from the work of the Canberra Group. ${ }^{1}$ In summary, these changes mean that the income measure is more comprehensive and thus better captures the extent of income inequality in Australia. However, the observed increases in income levels and in income inequality in recent years are likely to be exaggerated, although this means that inequality was higher in previous years than previously measured.

This chapter reviews the evidence on the redistributive impact of the Australian welfare state and how it has changed over time. It also discusses the comparative performance of the Australian welfare state and seeks to identify the implications of different analytical approaches for Australia's performance relative to those in other OECD countries.

Section 2 commences the main analysis by looking at how the design of Australia's welfare state differs from those in other OECD countries and summarises the

\footnotetext{
1 Implementation of the broader income measure in 2007-08 resulted in an \$85 increase in mean weekly gross household income, compared to the previous definition, a difference of roughly five per cent. The inclusions affected $3.4 \mathrm{~m}$ households in total (43 per cent). Most of the impact was on employment income, which increased by $\$ 89$ per week on average. The inclusion of non-cash employment benefits and bonuses had the most impact ( $\$ 43$ and $\$ 32$ per week respectively). In 2007-08, the Gini coefficient on the new basis was 0.331 , which is higher than that compiled on the former basis $(0.317)$. This reflects that most of the changes have been at the higher end of the income distribution i.e. the fourth and highest quintiles.
} 
conventional view in the social policy literature on the effectiveness of the Australian welfare state. In brief, this conventional view is that Australia is not very effective in reducing inequality despite high levels of progressivity in spending and taxes, primarily because of the low levels of spending and taxation. The most recent evidence from OECD income distribution studies supports this view, but in section $3 \mathrm{I}$ argue that there are significant conceptual and practical limitations to this approach. Section 4 looks at the implications of broadening the concept of resources for Australia's comparative performance. I conclude with a discussion of a number of further issues that could be considered in international comparisons of the effectiveness of welfare state arrangements and in comparisons of welfare state outcomes.

\section{The Australian welfare state and its impacts}

The Australian social security system differs markedly from those in other OECD countries. In Australia payments are flat-rate and financed from general taxation revenue, and there are no separate social security contributions; benefits are also income-tested or asset-tested, so payments reduce as other resources increase. Importantly, payments are not time-limited and continue for as long as people remain entitled.

In 2012, social expenditure in Australia was estimated to be 18.7 per cent of GDP (including pensions, unemployment payments, family payments, healthcare and community services) compared to an OECD average of 21.7 per cent, a level lower than the United States and Japan, and the tenth lowest in the OECD (OECD, 2013).

With taxes at about 27 per cent of GDP in 2008 compared to an OECD average of close to 35 per cent, Australia is the sixth lowest-taxing country in the OECD. Because of the absence of social security contributions, income tax takes a higher share of total tax revenue than in many other OECD countries, averaging 55-60 per cent of total revenue since 1980, compared to an OECD average of around one-third.

It is also important to note that the interactions between the tax and benefit systems can have significant implications for perceptions of levels of spending and also for redistribution. Adema and Ladaique (2005) show that accounting for private social benefits and the impact of the tax system on social expenditure has a significant equalising effect on estimated levels of social effort across OECD countries. For example, direct taxes (including social security contributions) paid on cash transfers are five per cent of GDP in Sweden and Denmark, but are less than 0.5 per cent of GDP in Australia. Indirect taxes on goods and services bought by benefit recipients are over two per cent of GDP in Nordic countries, 
but less than half that level in Australia. Non-pension tax expenditures (either tax credits similar to cash benefits or tax concessions aimed at stimulating the provision of private social benefits, but not including support for pensions) are of limited value in Nordic countries, but are close to two per cent or more of GDP in the USA (but only 0.4 per cent of GDP in Australia). Australia, however, has the highest level of pension tax expenditures in the OECD (Whiteford, 2010).

Australia also has a higher than average level of private social spending (Adema and Whiteford, 2010), with most spending on short-term sickness being provided by employers, and since 1992 mandatory private pensions have grown to cover more than 90 per cent of employees. The value of superannuation funds has grown from around 20 per cent of GDP in the early 1980s to more than 100 per cent by 2012, with annual payouts (mainly lump sums) exceeding public spending on age and related pensions.

\section{Liberal, residual or radical?}

Australia is often regarded as the epitome of the 'liberal' or residual welfare state; Esping-Andersen (1990) found Australia to have the lowest score on his de-commodification index, while Korpi and Palme (1998) found Australia was the only example of a targeted (rather than basic security) welfare state. These characterisations are disputed, however, by Gruen (1989) and by Castles and Mitchell (1990, 1993) who argue that Australia is one of a distinctive 'radical' group of nations, focusing its redistributive effort through the design of instruments rather than high expenditure levels.

When considering the redistributive impact of alternative transfer systems it is important to note that their design features differ in significant respects. Two of the most important features relate to the way benefits are funded - that is, the different ways in which programs are financed - and structured - that is, the relationship between benefits received and the past or current income of beneficiaries. Using these criteria, the social welfare systems of OECD countries are often characterised as either 'Bismarckian' or 'Beveridgean' (Werding 2003). In the first, social programs are based on social insurance principles, with earnings-related benefits, entitlement based on contribution records and funding through employer and employee social security contributions. In the second, policies are generally characterised by universal provision, with entitlement based on residence and in some cases need, and with benefits that are flat-rate and financed through general taxation. As previous discussion has suggested and later discussion will show, Australia can be considered a 'hyperBeveridgean' welfare system.

A related way of classifying and evaluating alternative welfare state arrangements is on the basis of the forms of redistribution emphasised in different institutional 
arrangements. Rather than focusing on the early architects of the welfare state this classification looks to the architecture itself. Barr (1992, 1999, 2001) points out that the main objective of transfer systems in most OECD countries is to provide insurance in the face of adverse risks (unemployment, disability, sickness) and to redistribute across the life-cycle, either to periods when individuals have greater needs (e.g. when there are children in the household) or would otherwise have lower incomes (such as in retirement). Barr (2001) describes this as the 'piggybank objective'.

The second main objective of the welfare state can be described as 'taking from the rich to give to the poor' (what Barr calls the 'Robin Hood' motive). Targeting of benefits is usually justified as a means of achieving the Robin Hood objective. Bismarckian-type welfare states can be characterised as giving priority to the piggy-bank objective, while Beveridgean-type welfare states give priority to the Robin Hood objective.

I would argue that the characterisation of Australia as a 'radical' welfare state is apt. Australia is the strongest example of a country using the 'Robin Hood' approach to the welfare state (Barr, 2001), relying more heavily on income-testing and directing a higher share of benefits to lower-income groups than any other OECD country. The poorest 20 per cent of the population receives nearly 42 per cent of transfer spending; the richest 20 per cent receives only around three per cent. As a result, as shown in Figure 1, in 2005 the poorest fifth received twelve times as much in cash benefits as the richest fifth, the highest ratio in the OECD and about 50 per cent more than the next most targeted country, New Zealand (Whiteford, 2010).

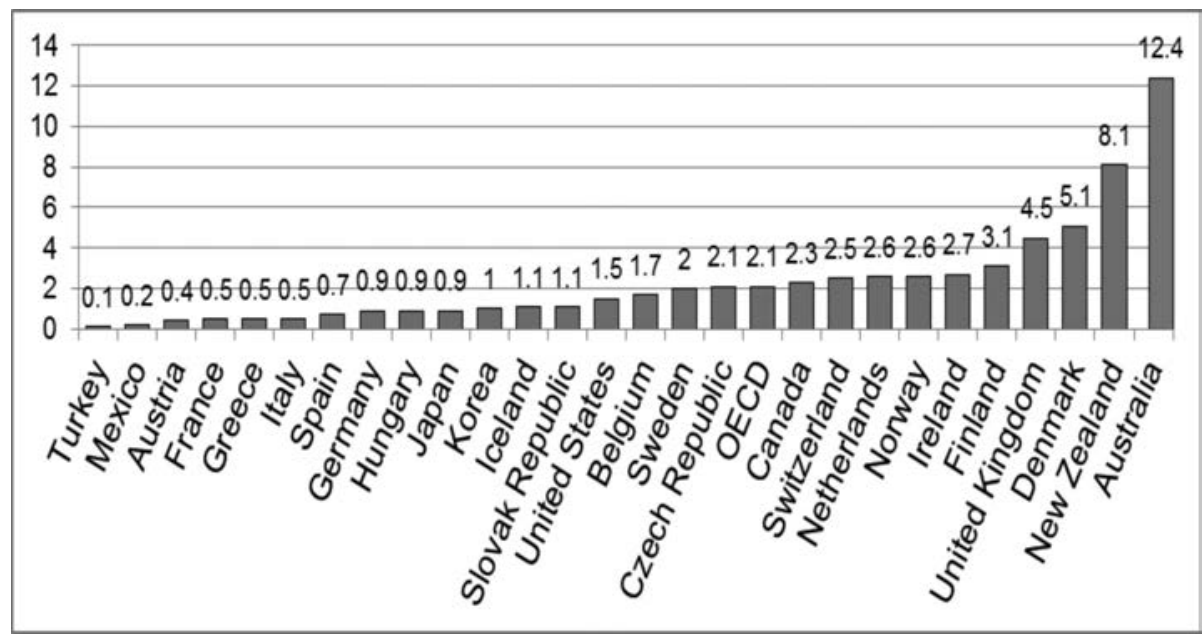

Figure 1 Progressivity of transfers, 2005. Ratio of cash benefits received by poorest 20 per cent of households to richest 20 per cent 
It is also worth noting, however, that the targeting of benefits in Australia is reinforced by the relatively high concentration of household joblessness (Whiteford, 2009); in this sense part of the reason why benefits are spread more widely across the income distribution in other countries is that people receiving social security payments are more likely to live in households with others not receiving payments; to some extent this implies that in these countries, inequality is 'hidden' within the household.

Because of its design features, Australia also has the most 'target efficient' system of social security benefits of any OECD country (OECD, 2008; Whiteford, 2010). Australia also has one of the most progressive systems of direct taxes of any OECD country (OECD, 2008), but the progressivity of taxes in Australia is not a consequence of particularly high taxes on the rich, but reflects the fact that lower-income groups in Australia pay much lower taxes than similar income groups in other countries (with the exception of the United States and Ireland). This is a result of the low level of direct taxes on social security recipients; effectively, any individual fully reliant on a social security payment will pay no income taxes.

The extent to which the Australian welfare state redistributes to the poor is determined by the interactions between the tax and social security systems, both in terms of the size of taxes collected and benefits paid and the distribution of taxes and benefits. Figure 2 shows 'net redistribution' to the poorest 20 per cent of the population around 2005 (Whiteford, 2010). This is calculated by estimating the level of spending on social security benefits as a percentage of household disposable income and then taking account of how much of this goes to the poorest fifth. The same procedure is used to calculate how much tax is paid by people in that group, which is then subtracted from the benefits received to give 'net redistribution to the poor'.

Even though Australia spends below the OECD average on social security benefits, the distribution of benefits is so progressive, and the level of taxes paid by the poor is so low, that Australia redistributes more to the poorest 20 per cent of the population than any other OECD country except Denmark (which spends about 80 per cent more than Australia). 


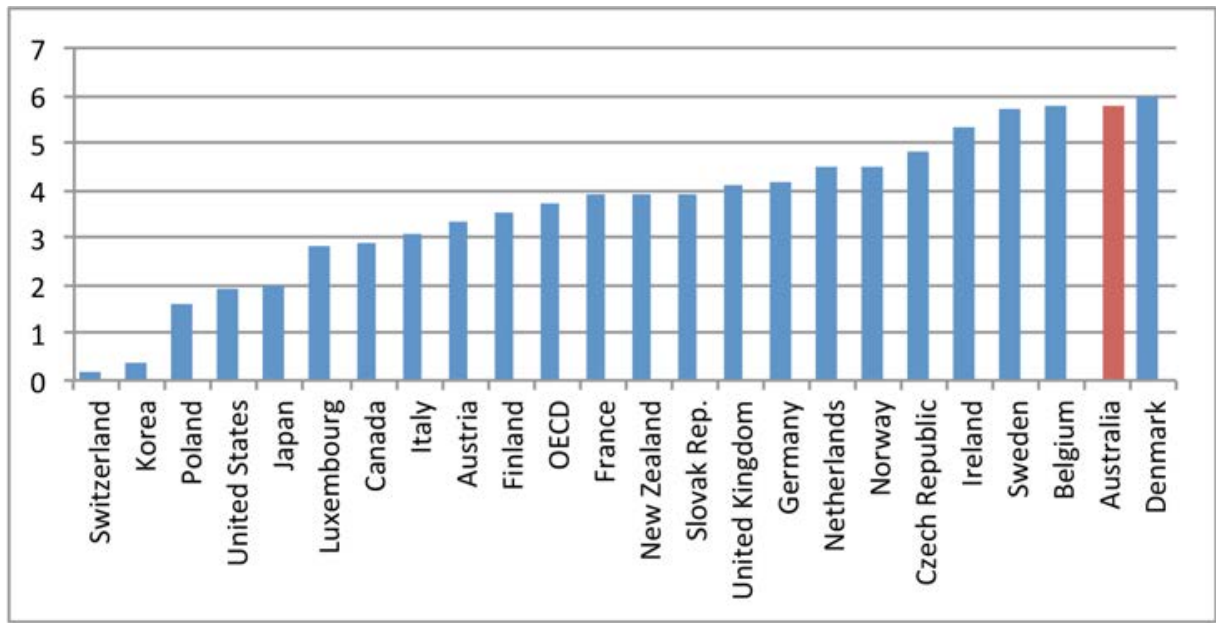

Figure 2 Net redistribution to the poor, 2005. Cash benefits after direct taxes received by poorest 20 per cent of households as a percentage of household disposable income

Source: Whiteford, 2010.

The differing designs of social programs influence the distribution of household incomes in different ways. In assessing these impacts it is important to distinguish between progressivity and redistribution. Progressivity refers to the profile of benefits when compared to market or disposable incomes; how large a share of benefits is received by different income groups? For example, do the poor receive more than the rich from the transfer system? Redistribution in contrast refers to the outcomes of different tax and benefit systems; how much does the benefit system actually change the distribution of household income?

The figures given above show that Australia has the most targeted and the most progressive transfer system among all rich countries, but this does not mean that it has the most redistributive system. This is because the level of redistribution is a product both of the progressivity of spending and the volume of spending - Australia has high progressivity but low spending. Put simply, a high spending but less progressive system may redistribute more than a lowspending but more progressive system. In this context, it is also important to look at the whole distribution and not just the poorest 20 per cent, as has been done in Figure 2. So what does the evidence show?

Figure 3 shows the most recent OECD (2013) figures on the level of household income inequality around 2010. Australia has the eleventh highest level of inequality among OECD countries, ranking between Canada and Japan. This represents a further change in Australia's ranking in recent years: OECD (2008) 
found that around 2005, Australia ranked fifteenth highest in the OECD, and just below the OECD average, while OECD (2011) found that in 2008 Australia had the eighth highest level of inequality in the OECD. The change in Australia's ranking between 2005 and 2008 reflects the changes made to ABS income surveys discussed previously, while the change between 2008 and 2010 reflects the accession of Chile to the OECD and the inclusion of Spain and Portugal in the 2010 figures but not the 2008 figures, plus a small fall in inequality in Australia in this period, which caused Australia to fall below Japan in rankings.

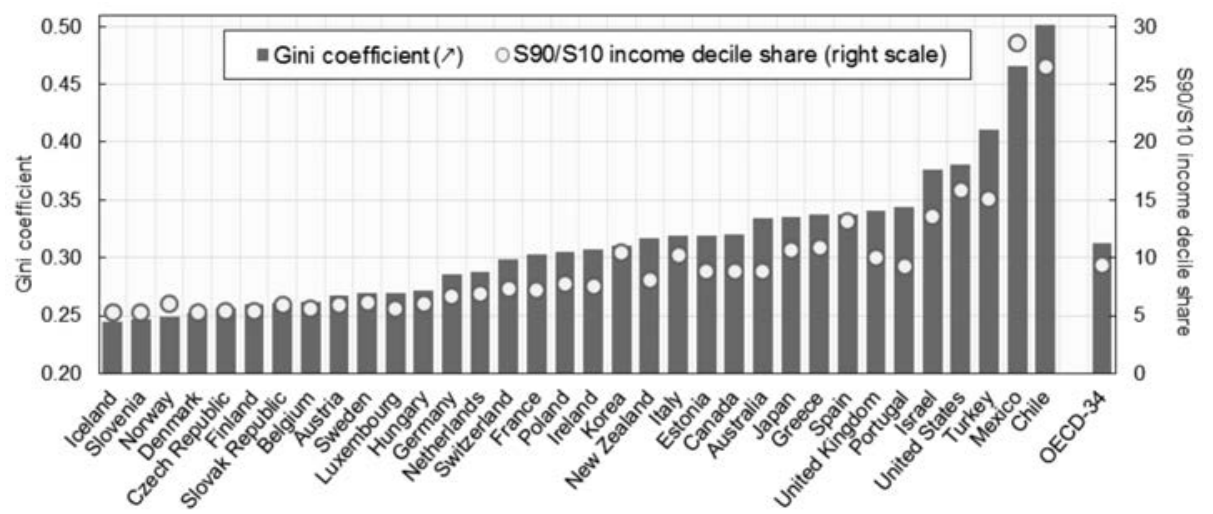

Figure 3 Level of inequality, OECD countries, around 2010

Source: OECD, 2013.

Figure 4 shows estimates calculated from the OECD (2013) database of the redistributive impact of cash transfers and direct taxes on income inequality as measured by changes in the Gini coefficient. Figure 4 shows that inequality reduction in Australia is currently the seventh lowest in the OECD, with the Gini coefficient for disposable income after taxes and transfers being less than 0.15 Gini points, with inequality reduction being greatest in Ireland at just over 0.25 Gini points. Overall this suggests that while Australia has the most progressive and target-efficient transfer system in the OECD, it is not particularly effective at reducing inequality. 


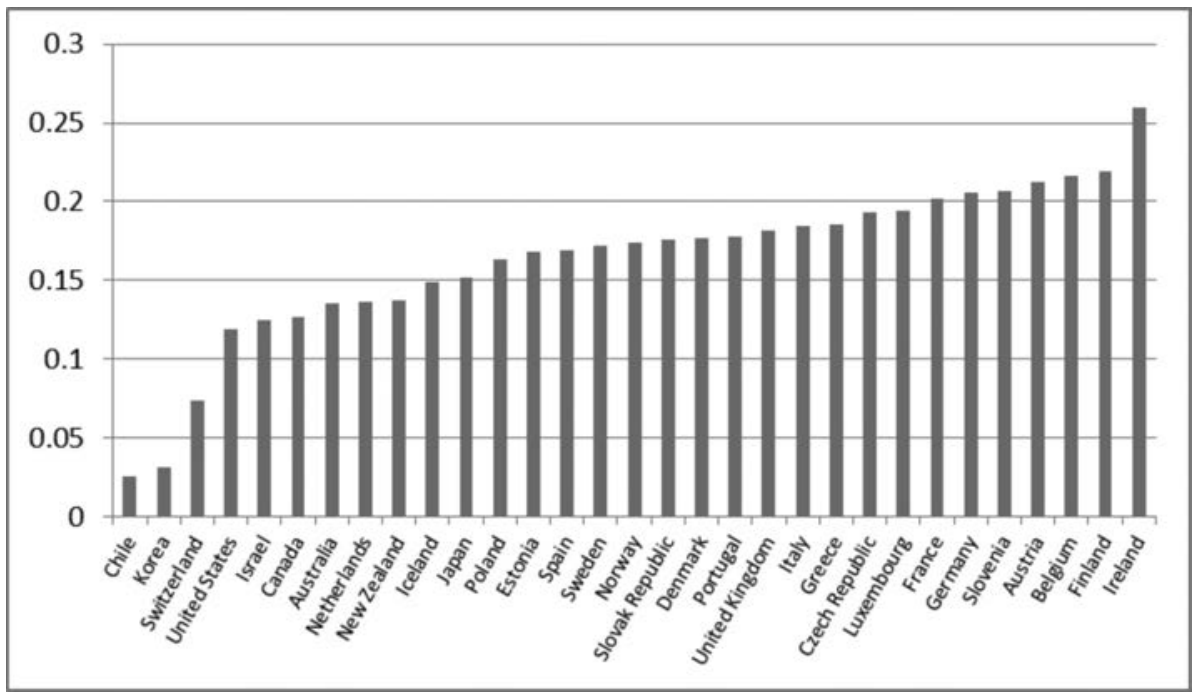

Figure 4 Reduction in inequality through transfers and taxes, OECD countries, 2010. Percentage point difference in Gini coefficient

Source: Calculated from OECD, 2013.

Why is this so? The main argument offered by some analysts is that referred to above, and discussed in more detail in Whiteford (1997) and Whiteford (2010): the Australian welfare state is less effective at reducing inequality than higher-spending welfare states because we simply fail to spend enough on social security transfers or raise enough in taxes to significantly reduce underlying inequality. Paradoxically, this is precisely because we have less middle class welfare than other countries (Barr, 1990; Korpi and Palme, 1998). This is because the degree of redistribution achieved by a benefits system depends on the 'quantum' of benefits as well as the progressivity of the formula for allocating benefits (Barr, 1992). A means-tested program with a highly redistributive formula may achieve limited redistribution if spending is low. That is, while the Australian system is more efficient than others, it is not as effective at reducing poverty (Mitchell, Harding and Gruen, 1994) or inequality. In contrast, a high cost, earnings-related system may achieve greater redistribution by providing more generous basic benefits (Korpi and Palme, 1998; Saunders, 1994). Other countries reduce inequality to a greater extent than Australia, because their tax and social security systems take a larger share of national income.

These arguments are of considerable significance to debates about the future of the Australian welfare state. They imply that if we wish to reduce inequality, then we should actually increase the level of taxes and welfare spending. Moreover, it suggests that we can achieve greater redistribution between rich and poor 
even if we have a less progressive tax system (for example, by increasing the GST) and a less targeted social security system (more universal or even earningsrelated benefits).

In earlier work (Whiteford and Kennedy, 1995; Whiteford, 1997, 2010) I have argued that there are a number of significant problems with such an analysis. Overall, the weight of these arguments is that the apparent failure of the Australian approach to redistribution to substantially reduce inequality is at least partly an artefact of the methods used to measure inequality and income redistribution. The discussion that follows argues that international comparisons have a number of biases that may lead to a mis-estimation of the redistributive impact of the welfare state, because the methodological framework used to reach these conclusions is usually incomplete.

\section{Measuring income inequality: The standard approach and its problems}

\section{An accounting framework for household income}

By definition, any numerical assessment of income inequality must deal with a range of technical questions (Gruen, 1989; Whiteford, 1997), including the concept of living standards, the measure of material resources, the treatment of wealth, the time period over which income is measured, the unit assumed to share income, and the treatment of families or households with differing needs. All income distribution studies must make precise decisions about each issue. For many issues there is no one 'correct' answer so the choice of a particular approach is arbitrary in the sense that there can be good reasons for making different choices. But results can differ significantly if different decisions are made about any issue

Underlying all comparisons of welfare state outcomes is a framework for analysing the process of income distribution and redistribution (EspingAndersen 1990). The results presented above employ what Ringen (1987) has called 'the standard approach' to analysing income distribution data. As set out in Table 1, essentially this is an accounting framework for relating different income components and for deriving aggregates such as gross income and cash disposable income. When using microdata, this framework is applied to each household's income to produce the income measures identified. These household or income unit accounts are aggregated and analysed to produce measures of distribution and redistribution for the population as a whole. The redistribution achieved by taxes or transfers is calculated by comparing income shares, Gini coefficients, or poverty indexes at different stages in the process outlined. 
Measuring and Promoting Wellbeing: How Important is Economic Growth?

Table 1 The Income Accounting Framework

\begin{tabular}{|c|}
\hline $\begin{array}{l}\text { Wages and salaries } \\
++\end{array}$ \\
\hline $\begin{array}{c}\text { Self-employment income } \\
+\end{array}$ \\
\hline $\begin{array}{l}\text { Property income } \\
=\end{array}$ \\
\hline $\begin{array}{l}\text { 1. Factor income } \\
+\end{array}$ \\
\hline $\begin{array}{c}\text { Occupational and private pensions } \\
=\end{array}$ \\
\hline $\begin{array}{l}\text { 2. Market income } \\
+\end{array}$ \\
\hline $\begin{array}{c}\text { Social security cash benefits } \\
\text { (universal, income-related, contributory) } \\
+\end{array}$ \\
\hline $\begin{array}{l}\text { Private transfers } \\
+\end{array}$ \\
\hline $\begin{array}{l}\text { Other cash income } \\
=\end{array}$ \\
\hline $\begin{array}{c}\text { 3. Gross income } \\
-\end{array}$ \\
\hline $\begin{array}{c}\text { Income tax (and employee social security contributions) } \\
=\end{array}$ \\
\hline $\begin{array}{l}\text { 4. Cash disposable income } \\
\mathrm{x}\end{array}$ \\
\hline $\begin{array}{c}\text { Equivalence scales } \\
=\end{array}$ \\
\hline 5. Equivalent cash disposable income \\
\hline
\end{tabular}

Source: Whiteford, 2010.

While this framework has been used by virtually all international studies including the results given in Figure 4 - there are obvious limitations to the approach. These problems are discussed below, and include: the counterfactual against which to measure redistribution; the comprehensiveness of the income framework, particularly the omission of important components of the welfare state from standard analysis; and the relationship between public and private welfare. In many ways these problems are interlinked, although the discussion below separates them.

These problems affect analysis of the degree of underlying inequality; they affect the measurement of the effectiveness and efficiency of the welfare state itself; and they affect the measurement of the final outcomes of redistributive policy. Consequently, they also impact on any policy inferences drawn from international comparisons. It is extremely important to note that the work of 
the Canberra Group is designed to address a number of these conceptual and methodological issues and as a result of their work the ABS, the OECD and Eurostat have augmented their analyses of income distribution. These broader measures go a long way to reducing the problems to be discussed, although there are a number of important challenges remaining.

\section{The counterfactual}

Any assessment of the distributional impact of the welfare state involves a comparison of the observed distribution with a counterfactual - the hypothetical distribution existing in the absence of the policies evaluated (Pedersen, 1994). Table 1 relies on a counterfactual in which the welfare state has had no behavioural effects on the 'underlying' income distribution. The framework is linear, implying that the distribution of market incomes precedes the operation of the tax-transfer systems, and there have been no interactions between them, apart from the direct effect of government programs in reducing inequality. Crucially, it is also assumed that the wide variations in the scope of different welfare states have had the same (zero) behavioural impact in each country.

As argued by Layard (1977) and Reynolds and Smolensky (1977), however, to the extent that the welfare state displaces private savings or other activities, the standard approach exaggerates market or private income inequality and then exaggerates the amount of redistribution achieved by the welfare state. At the simplest level this can be seen as a result of adverse behavioural incentives associated with welfare state programs, for example, incentives to lone parenthood said to be associated with welfare benefits for lone parents (Murray, 1984) or lengthening durations of unemployment potentially caused by extended entitlements to unemployment insurance. In particular, however, in countries with generous public pensions, the standard approach implies that middle class individuals are plunged into market income poverty on retirement simply because it is the government, rather than the market, that provides their pensions: generous earnings-related public pensions are then measured as being very effective at reducing inequality, in part because they restore middleincome retirees to their pre-retirement ranking. Effects of this sort are not so much behavioural as mechanical.

\section{How should we rank?}

As noted above, in the standard approach the degree of redistribution achieved by cash transfers is measured as the difference between the Gini coefficient (or other inequality measure) for market incomes and the Gini coefficient for gross incomes, and the redistributive effect of taxes is measured as the difference 
between the Gini coefficient for gross incomes and that for disposable incomes. The question therefore is how much of this redistribution is due to the reranking associated with welfare state programs.

Table 2 shows the effects of using different income concepts for ranking households on the distribution of benefits and taxes. For example, if households are ranked by their private incomes then the cash benefits received by the poorest 20 per cent of Australians are 29 times as great as those received by the richest quintile, while the income taxes paid by the richest 20 per cent are 756 times those paid by the poorest 20 per cent. In this context, it is worth noting that cash benefits are income-tested on the basis of private income, so as a measure of the degree of targeting in the benefit system this is arguably the most appropriate income concept to rank by.

However, if households are ranked by their gross income (i.e. private income plus cash transfers) then the progressivity of both direct and indirect spending is measured as being much lower, as is the progressivity of income taxes, while the distribution of indirect taxes actually becomes somewhat more propoor. This re-ranking occurs because some people with measured low private incomes do not receive social security benefits. As noted by the ABS (2012), 'Some households report extremely low and even negative income in the survey, which places them well below the safety net of income support provided by government pensions and allowances. Households may under-report their incomes in the survey at all income levels, including low-income households. However, households can correctly report low levels of income if they incur losses in their unincorporated business or have negative returns from their other investments'. Some of these apparently low-income households do not claim social security benefits. So re-ranking occurs because these people stay in the bottom quintile, while some people receive enough in social security to move them up the income distribution. It is also worth noting that while some social security payments are not taxable, it could be argued that gross income is the most appropriate income concept to assess the progressivity of taxes on income, since income taxes are paid out of gross income.

Ranking by disposable income increases the measured progressivity of cash benefits and transfers in kind but reduces the apparent progressivity of direct and indirect taxes. The earlier results in Figure 4 are based on ranking by disposable income, and these results suggest that progressivity in the distribution of transfers has increased since the first OECD results for 2003, since the Q1/Q5 ratio has increased from around 12 to 1 to nearly 15 to 1 since then. However, the progressivity of income taxes has declined since 2003 when the richest quintile paid nearly 69 times as much in tax as the poorest quintile, with the most recent figure being close to 49 times as much. 
Ranking by final income causes significant changes with all measures of the progressivity of taxes and transfers being lower. This reduced progressivity reflects large scale re-ranking of households, with older people benefiting from large transfers in kind through the health care system, while higher income households with children benefit from education spending.

Table 2 Effects of different income rankings on distribution of benefits and taxes, Australia, 2009-10

\begin{tabular}{|c|c|c|c|c|}
\hline Private income & $\begin{array}{l}\text { Social assistance } \\
\text { benefits in cash }\end{array}$ & $\begin{array}{l}\text { Taxes on } \\
\text { income }\end{array}$ & $\begin{array}{l}\text { Social transfers } \\
\text { in kind }\end{array}$ & $\begin{array}{l}\text { Taxes on } \\
\text { production }\end{array}$ \\
\hline \multicolumn{5}{|c|}{ Private income } \\
\hline Lowest quintile & $\$ 435$ & $\$ 1$ & $\$ 455$ & $\$ 105$ \\
\hline Highest quintile & $\$ 15$ & $\$ 756$ & $\$ 234$ & $\$ 273$ \\
\hline Ratio* & 29.00 & 756.00 & 1.94 & 2.60 \\
\hline \multicolumn{5}{|c|}{ Gross income } \\
\hline Lowest quintile & $\$ 281$ & $\$ 2$ & $\$ 319$ & $\$ 89$ \\
\hline Highest quintile & $\$ 45$ & $\$ 809$ & $\$ 363$ & $\$ 309$ \\
\hline Ratio* & 6.24 & 404.50 & 0.88 & 3.47 \\
\hline \multicolumn{5}{|c|}{ Disposable income } \\
\hline Lowest quintile & $\$ 323$ & $\$ 15$ & $\$ 442$ & $\$ 114$ \\
\hline Highest quintile & $\$ 22$ & $\$ 731$ & $\$ 239$ & $\$ 275$ \\
\hline Ratio* & 14.68 & 48.73 & 1.85 & 2.41 \\
\hline \multicolumn{5}{|c|}{ Final income } \\
\hline Lowest quintile & $\$ 224$ & $\$ 38$ & $\$ 293$ & $\$ 142$ \\
\hline Highest quintile & $\$ 43$ & $\$ 745$ & $\$ 305$ & $\$ 263$ \\
\hline Ratio* & 5.21 & 19.61 & 0.96 & 1.85 \\
\hline
\end{tabular}

Note: The figures for the lowest and highest quintiles are the dollar values in 2009-10 of the average benefits received and taxes paid by the income quintile. The ratios for social assistance benefits and social transfers received are the ratio of the lowest quintile to the highest quintile; the ratios for taxes on incomes and taxes on production are the ratio of the highest quintile to the lowest quintile.

Source: Calculated from ABS, Government Benefits, Taxes and Household Income, Australia, 2009-10, Catalogue No. 6537.0.

Overall it is apparent that the income measure used for ranking households has a significant impact on the assessment of the progressivity of the different transfer and tax instruments, and that more comprehensive income measures show lower progressivity than do less comprehensive income measures.

Having said this, it is also important to note that more comprehensive income measures show much lower income inequality than less comprehensive measures, although there are differences according to the ranking measure. Table 3 shows the Q5 to Q 1 ratio for different income concepts and different rankings. When households are ranked by their private incomes, equivalised 
private income is very unequally distributed with the highest income quintile having incomes more than 21 times as great as the lowest income quintile; the receipt of social security benefits reduces this disparity to about 6 to 1 and the deduction of income taxes reduces this further to under 5 to 1 . In-kind transfers reduce this further to just under 3 to 1 , while indirect taxes increase this marginally. When households are ranked by their final income, however, the Q5/Q1 ratio for private income is less than 8 to 1 showing that most of the reduced progressivity is due to the re-ranking of people in terms of their private income. Put another way, disparities in final income vary by much less when different income rankings are used than do disparities in private income.

Table 3 Income disparities under different income rankings, Australia, 2009-10. Q5/Q1

\begin{tabular}{|l|c|c|c|c|c|}
\hline & $\begin{array}{c}\text { Private } \\
\text { income }\end{array}$ & $\begin{array}{c}\text { Gross } \\
\text { income }\end{array}$ & $\begin{array}{c}\text { Disposable } \\
\text { income }\end{array}$ & $\begin{array}{c}\text { Disposable } \\
\text { income plus } \\
\text { transfer in kind }\end{array}$ & $\begin{array}{c}\text { Final } \\
\text { income }\end{array}$ \\
\hline Equivalised private income & 21.47 & 6.03 & 4.81 & 2.97 & 3.01 \\
\hline $\begin{array}{l}\text { Equivalised disposable } \\
\text { income }\end{array}$ & 13.71 & 6.21 & 5.10 & 3.11 & 3.21 \\
\hline Equivalised final income & 7.96 & 5.44 & 4.62 & 3.51 & 3.80 \\
\hline
\end{tabular}

Source: Calculated from ABS, Government Benefits, Taxes and Household Income, Australia, 2009-10, Catalogue No. 6537.0.

Is there a 'right' income measure by which to rank households? The answer is probably no. In this context, it is worth noting that the equivalence scales used to adjust for household size are those related to cash incomes, but receipt of transfers in-kind raises complex issues relating to the needs of households. For example, generally households receiving large benefits from health care spending are experiencing illness or disability and their needs for health care are not captured by conventional equivalence scales.

Do the issues raised by re-ranking have implications for an assessment of the effectiveness of the Australian tax-transfer system? The answer appears to be yes - the income measure used for ranking can have major implications for the measurement of redistribution across countries.

Figure 5 shows two measures of the 'effectiveness' of the tax and benefit systems in reducing income inequality in OECD countries: the percentage reduction in income inequality when moving from market income to disposable income (in the top panel), and the absolute point difference between these two measures (in the bottom panel) (OECD, 2008). 


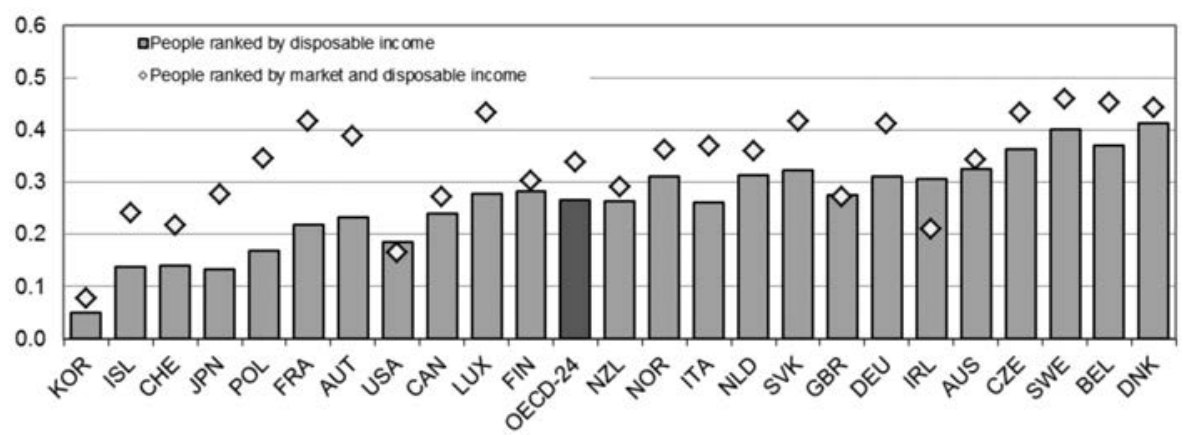

Figure 5a Differences in inequality before and after taxes and transfers in OECD countries. Difference in concentration coefficients, mid-2000s. Percentage reduction

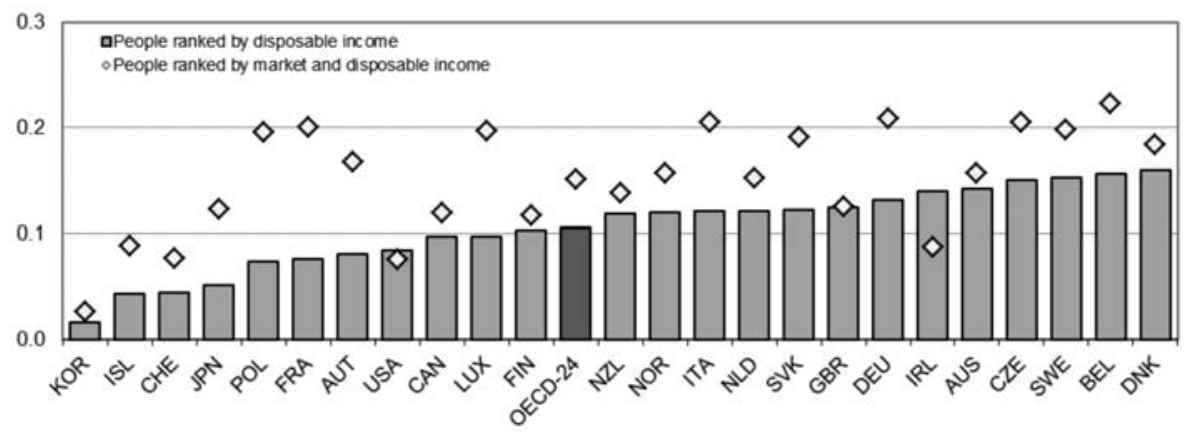

Figure 5b Differences in inequality before and after taxes and transfers in OECD countries, Difference in concentration coefficients, mid-2000s. Point reduction.

Note: Countries are ranked, from left to right, in increasing order of the percentage point reduction in the concentration coefficient achieved by household taxes and public cash transfers, based on people ranked by their household disposable income. Bars are computed based on grouped data for average market and disposable income, by deciles of people ranked by their household disposable income. Diamonds are computed based on individual data, with people ranked by market income (for the Gini coefficient of market income) and ranked by disposable income (for the Gini coefficient of disposable income).

Source: OECD income distribution questionnaire.

These measures are calculated in two ways. In the first approach (shown as diamonds), inequality in the distribution of market income is computed by ranking people by their level of market income. On this measure, on average, across the twenty-four countries covered, the tax and transfer systems lower income inequality by around one-third (i.e. around 0.15 Gini points), with declines ranging from around 45 per cent in Denmark, Sweden and Belgium to less than eight per cent in Korea. 
In the second approach (shown as bars) the Gini coefficient for market income is based on people ranked by their disposable income, that is, individuals are ranked by where they end up 'after' redistribution, rather than where they were placed 'before' redistribution. On this second measure, the reduction of inequality achieved by taxes and transfers is a little more than one-fourth (i.e. 0.11 points), with declines ranging from around 40 per cent in Sweden and Denmark to five per cent in Korea.

The difference between the two measures of redistribution is a result of the reranking of some households as a consequence of welfare state programs (Ankrom 1993). A comparison between the two measures suggests that, in some OECD countries, a very significant part of the redistribution measured by the standard approach reflects such a re-ranking of people. In particular, the countries where the re-ranking effect is most significant are those where public pensions account for more than 90 per cent of the total disposable income of the retirement-age population (i.e. Austria, Belgium, France, Italy, Luxembourg and Sweden). In contrast, re-ranking is lower in Korea, the United States, Canada, Finland, the United Kingdom, Ireland and Australia, where public pensions are 50 per cent or less of the disposable income of the retired.

The effect on Australia's relative performance is very large, primarily because there is little difference between the Australian results on the two rankings. Using the percentage point reduction in the Gini coefficient Australia moves from being the fifteenth most effective country in the OECD in reducing inequality to the fifth most effective. Australia also ranks fifth in terms of the proportional reduction, although it can be argued that since this measure is sensitive to the degree of inequality in market incomes, it is the point reduction that gives a more accurate picture of the extent of redistribution.

It is important to note, however, that this does not change Australia's ranking in terms of inequality of disposable incomes; all it suggests is that other OECD countries are not so effective in reducing inequality through the welfare state as the standard approach implies. This suggests that redistribution is exaggerated because the 'original' level of private income inequality is not as high as estimated. The level of disposable income inequality is unaffected by this adjustment. It should also be remembered that this conclusion applies to the period around 2005 (specifically 2003 in the case of Australia), and there is evidence that the redistributive impact of taxes and transfers declined somewhat between 2003 and 2008, but increased between 2008 and 2010, partly due to the fiscal stimulus in 2008 and 2009 and the pension increase in 2009. 


\section{Broadening the measure of resources}

A second major set of issues relates to the fact that the standard framework is incomplete. Most income surveys include information only on cash transfers and direct taxes, which form different fractions of overall government activity in different countries. Most standard comparative studies ignore the impact of broad-based consumption taxes and government non-cash benefits such as health, education and public housing. Consumption taxes tend to be regressive by income, and are much higher in large welfare states than in small welfare states. Non-cash benefits tend to be less progressive than targeted or universal cash transfers, but vary in significance by less than cash benefits.

\section{The effects of government services and indirect taxes}

\section{The Australian evidence}

The discussion of the standard approach has focused on the impact of cash transfers and direct taxes, but governments also redistribute resources to households through the provision or financing of public services, and they also finance spending through indirect taxes. A comprehensive accounting of the impact of government therefore needs to take these into account. As noted earlier, the ABS has published estimates of the redistributive impact of noncash benefits and indirect taxes for 1984, 1988-89, 1993-94, 1998-99, 2003-04 and most recently for 2009-10, with the first estimates being prepared while Ian Castles was Australian Statistician. As with income distribution statistics, major changes have been made to the methodologies for imputing the value of non-cash benefits and indirect taxes, with the result that the series is not fully comparable over time. ${ }^{2}$

Figure 6 shows ABS estimates of income disparities by income concepts for successive studies from 1984 to 2009-10. It is particularly important to note that households are ranked by gross income quintiles, and income measures are not equivalised. In 1984 the highest gross income quintile received 6.1 times the disposable income of the poorest quintile, but after adding non-cash benefits and deducting indirect taxes, this disparity was reduced to 4.5 to 1 . Over the period shown, income disparities widened for disposable income, but initially narrowed in respect of final income, before rising again in the 1990s. As noted,

2 Up until 1998-99, the ABS did not adjust by equivalence scales and households were ranked by gross income. In 2009-10 major improvements were made: a more comprehensive measure of private income, including net imputed rent for owner-occupied dwellings and the net benefit that can be attributed to households living in subsidised private rentals; improvements to the allocation of transfers in-kind for health benefits, housing benefits and child care assistance; inclusion of electricity concessions provided by state/ territory governments for the first time; and, improvements to the methodology for estimating taxes on ownership of dwellings. 
the latest two studies involve a changed definition of private income since they include imputed income from owner-occupied housing and private rental subsidies. This broadening of the income concept has a substantial impact on disposable income inequality, with the Q5/Q1 ratio for disposable income being lower in 2003-04 and 2009-10 than shown using the different income measure for 1998-99.

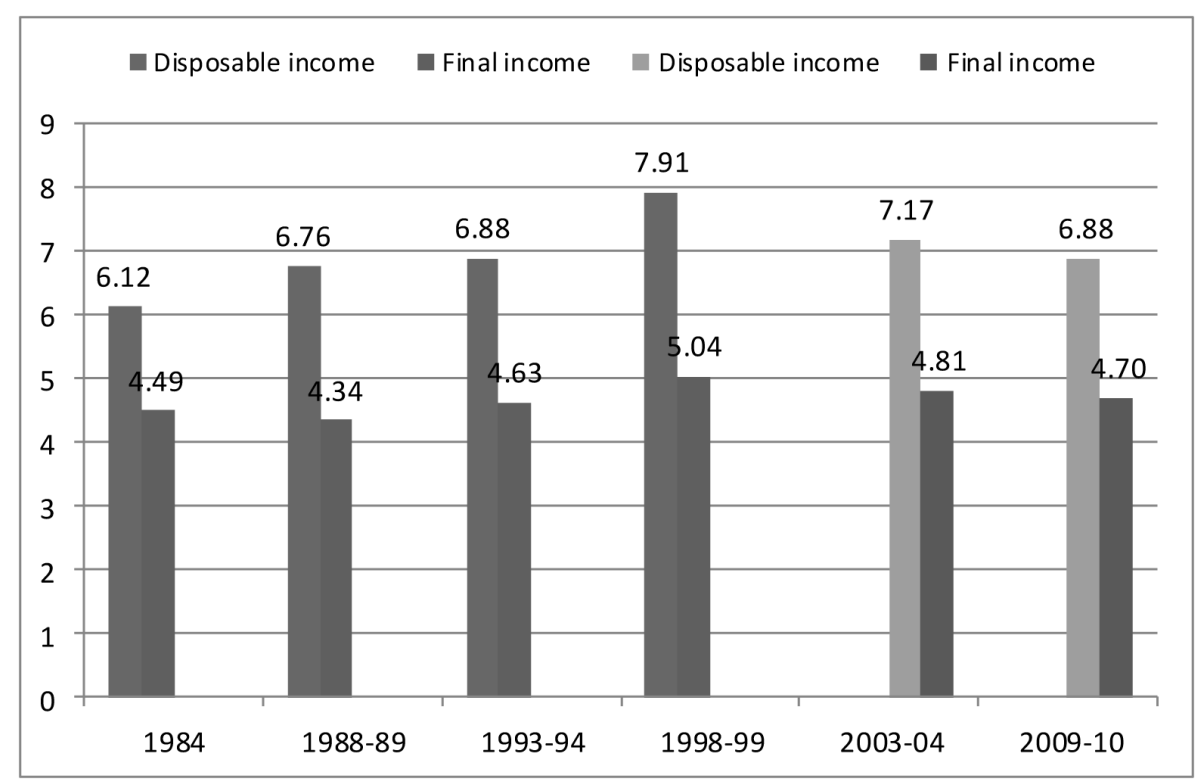

Figure 6 Income disparities by income concept, Australia, 1984 to 200910. Ratio of $Q 5$ to $Q 1$

Source: Calculated from ABS, Government Benefits, Taxes and Household Income, various years.

These figures are of interest in showing trends over the longer term, but conceptually results for equivalised income concepts are preferred. 


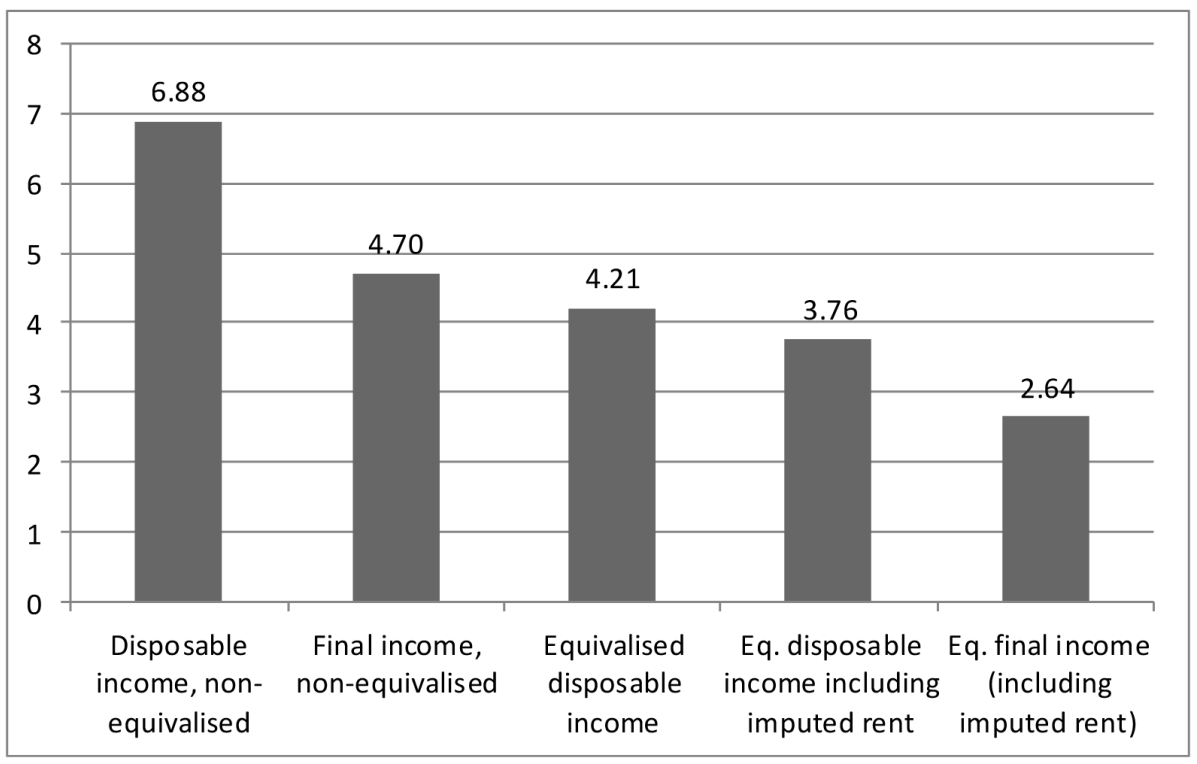

Figure 7 Income disparities by income concept, Australia, 2009-10. Ratio of 05 to 01

Source: Calculated from ABS, Government Benefits, Taxes and Household Income, 2009-10.

Figure 7 shows equivalised household income distributions for different income concepts in 2009-10. Including the impact of imputed rent and taking account of non-cash benefits and indirect taxes significantly reduces estimated inequality. Adding imputed rent to disposable income reduces disparities by close to 11 per cent and adding non-cash benefits and indirect taxes reduces this measure of inequality by a further 30 per cent.

A recent Productivity Commission Staff Working Paper (Greenville, Pobke and Rogers, 2013) calculates that the Gini coefficient for equivalised final income (excluding imputed income from owner-occupied housing and other housing subsidies) increased from 0.248 in $1988-89$ to 0.270 in 2009-10. They also calculate that the Gini for equivalised disposable income in the same data (the 2009-10 Household Expenditure Survey) was 0.344 and the Gini for equivalised disposable income plus non-cash benefits but excluding indirect taxes was 0.257 , suggesting that spending on non-cash benefits reduces inequality by 0.087 Gini points or about 25 per cent, but indirect taxes raise inequality by 0.013 Gini points or about five per cent.

\section{The international evidence}

International studies of the impact of government cash and non-cash benefits and direct and indirect taxes have been undertaken for some considerable time. 
The UK Central Statistical Office has published such estimates since the 1960s with figures available online for results from 1977 onwards. Their approach influenced the ABS in undertaking their first study based on the 1984 Household Expenditure Survey. Ian Castles himself undertook an early comparative study in his 1987 paper referred to earlier, in which he compared results for Australia in 1984, New Zealand in 1981-82, and Sweden, the United Kingdom and the United States in 1984 (although a differing approach in the USA meant that some comparisons were limited, and results for Sweden and the United States do not take account of non-cash benefits and indirect taxes).

Table 4 shows some of these results, presenting Gini coefficients for private, gross, disposable income, disposable income and indirect benefits and for final income. The results are also adjusted for household size, although this adjustment is relatively crude, as the Castles study did not have microdata for the other countries. Table 4 shows that disposable income inequality was lowest in Sweden and highest in the United States, with Australian income inequality being second highest, although the gap between Australia and the USA was considerable. However, non-cash benefits appear to have had a stronger equalising effect in Australia than in the United Kingdom or New Zealand, and indirect taxes had a very small impact in all three countries. The overall result was on the basis of final income - Australia was slightly less unequal than New Zealand or the United Kingdom, but the differences were very small. Overall, the impact of this broadening of the income concept appears to have been a small degree of re-ranking of countries in the middle of this limited international distribution. ${ }^{3}$

Other relatively early comparative studies of the effects of non-cash benefits on income distribution include Smeeding, Saunders et al (1992) and Whiteford and Kennedy (1995). Smeeding, Saunders et al (1992) compare the impact of including the value of health and education benefits in income for Australia, Canada, Germany, the Netherlands, Sweden, the United Kingdom and the United States, plus imputed income from owner-occupied housing in these countries, apart from Australia and the UK. Adding these non-cash benefits had a relatively minor impact on income disparities in West Germany and Sweden, with larger impacts in the United States and Canada and the most significant effect in the Netherlands, which ranked third lowest in terms of disposable income inequality but lowest in terms of final income inequality, primarily due to the effects of imputed housing income. Smeeding, Saunders et al (1992)

3 It is worth noting that if the Q5 to Q1 ratio is used rather than the Gini coefficient, then the United Kingdom was slightly less unequal than Australia, which suggests that some care should be taken with conclusions based on this ratio, given the greater validity of the Gini coefficient as a measure of overall inequality. 
found that the impact on relative poverty rates was much greater, particularly in Australia and the United Kingdom, where poverty rates fell by two-thirds and half, respectively.

Table 4 Approximate Gini coefficients for alternative income measures in five countries, early to mid-1980s

\begin{tabular}{|l|l|l|l|l|l|}
\hline & $\begin{array}{l}\text { Private } \\
\text { income }\end{array}$ & $\begin{array}{l}\text { Gross } \\
\text { income }\end{array}$ & $\begin{array}{l}\text { Disposable } \\
\text { income }\end{array}$ & $\begin{array}{l}\text { Disposable } \\
\text { income and } \\
\text { indirect } \\
\text { benefits }\end{array}$ & Final income \\
\hline \multicolumn{6}{|c|}{ Ranked by private income } \\
\hline Australia & 0.469 & 0.363 & 0.314 & 0.263 & 0.263 \\
\hline New Zealand & 0.433 & 0.336 & 0.290 & 0.267 & 0.266 \\
\hline Sweden & 0.521 & 0.294 & 0.258 & - & - \\
\hline $\begin{array}{l}\text { United } \\
\text { Kingdom }\end{array}$ & 0.491 & 0.354 & 0.311 & 0.269 & 0.264 \\
\hline \multicolumn{7}{|c|}{ Ranked by gross income } & \\
\hline Australia & 0.462 & 0.370 & 0.325 & 0.278 & 0.279 \\
\hline $\begin{array}{l}\text { United } \\
\text { Kingdom }\end{array}$ & 0.486 & 0.363 & 0.324 & 0.288 & 0.286 \\
\hline United States & 0.459 & 0.406 & 0.369 & - & - \\
\hline
\end{tabular}

Source: Castles, 1987, Table H: 14.

Whiteford and Kennedy (1995) replicated this methodology, but were able to add imputed housing benefits for Australia and the United Kingdom, but not for the Netherlands and Sweden. Their results were broadly similar to Smeeding, Saunders et al (1992), although it can be noted that the reduction in inequality achieved was greatest in Australia. Once again, the effects on relative poverty rates were much greater than the effects on income inequality.

Since that time there have been many studies that take account of the impact of non-cash benefits, as well as studies that take account of the effects of indirect taxes. However, in quite a number of these studies the two instruments of redistribution are assessed separately. For example, in the study Growing Unequal, the OECD (2008) analysed the distributional effects of non-cash benefits in OECD countries around 2000, assessing the impact of health, education, social housing and other community services on income disparities.

Figure 8 shows the reduction in income disparities estimated by the OECD (2008), with the reduction in the Q5 to Q1 ratio varying between 0.5 in Luxembourg (i.e. from 3.8 to 3.2) and 2.6 in the USA (from 7.1 to 4.6). 


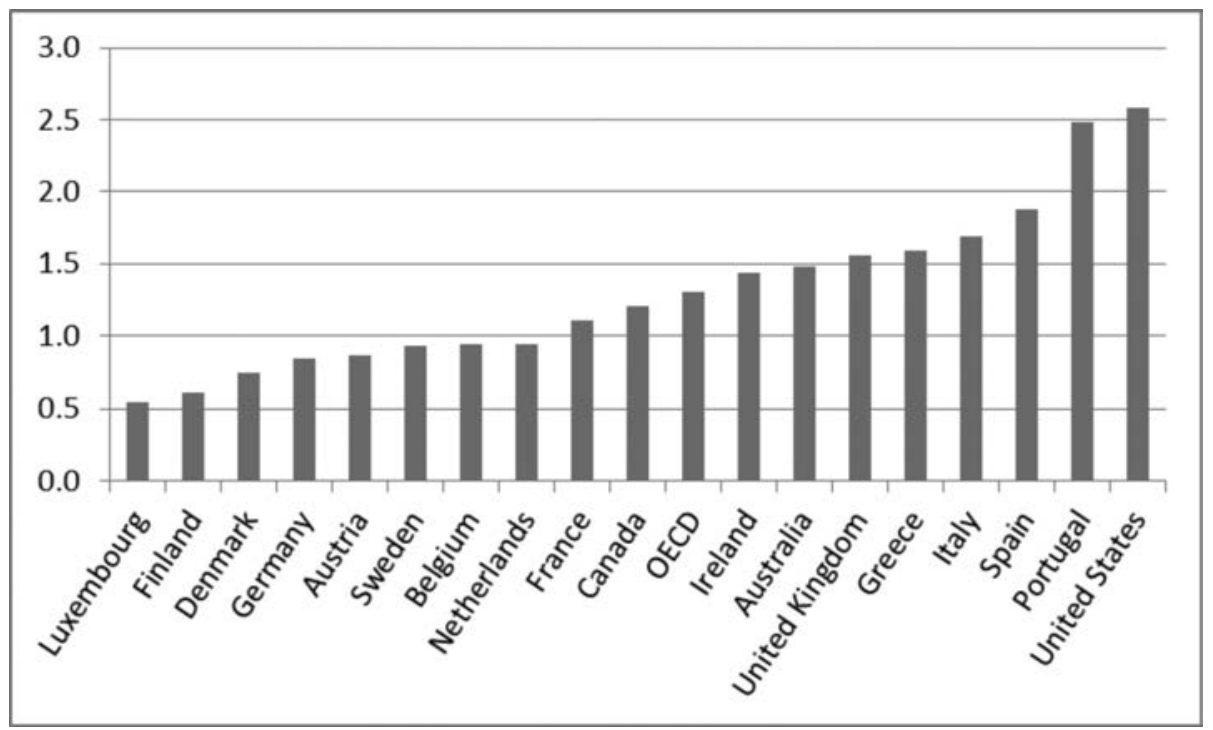

Figure 8a Reduction in inter-quintile share ratio after inclusion of non-cash benefits, selected OECD countries, around 2000. Reduction in ration of 05 to 01

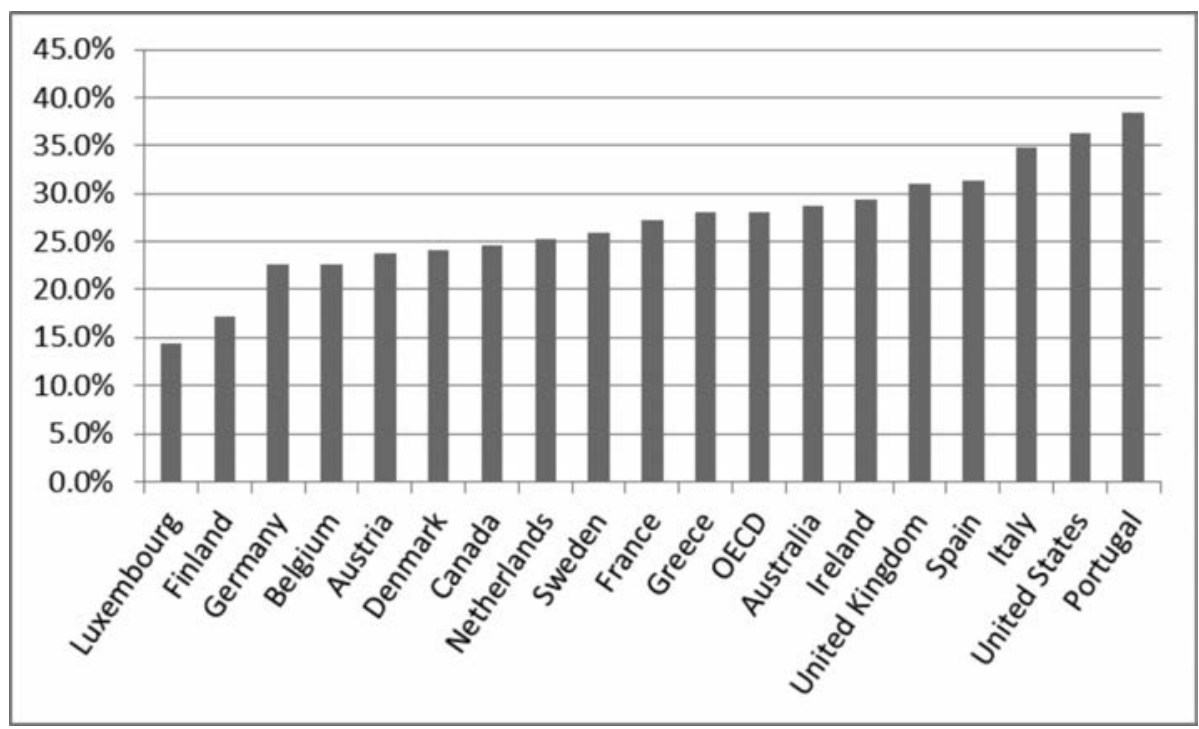

Figure $8 \mathrm{~b}$ Reduction in inter-quintile share ratio after inclusion of non-cash benefits, selected OECD countries, around 2000. Percentage reduction in ratio of 05 to 01

Source: Calculated from OECD, 2008: 234.

The reduction estimated for Australia was slightly above average from 5.0 to 3.5, or by nearly 29 per cent. Generally speaking it was found that public spending 
on health had the largest impact in reducing income disparities, with the effect being about 50 per cent higher on average, but being nearly twice as important in Australia than the impact of education spending. While the inclusion of noncash benefits had no effect on Australia's international ranking (staying the fifth most unequal of these countries) a number of countries did change their ranking, but mainly to a limited degree; Finland, however, fell four places from second least unequal to sixth least unequal.

The subsequent OECD report, Divided We Stand: Why Inequality Keeps Rising (2011, Part III, Chapter 8) undertook a similar analysis on a wider range of countries for the period around 2007. In Australia the reduction in the interquintile share ratio was estimated to be from 5.35 to 3.81 or 29 per cent, a percentage reduction identical to the earlier results and around the average of the 27 countries included. However, OECD (2011) also calculated the effects on the reduction in the Gini coefficient, which in the case of Australia was 17 per cent, below the OECD average of 20 per cent, and equal fourth lowest among these countries. This resulted in a relatively large change in Australia's international ranking, so that it fell from seventeenth to twenty-first in the OECD ranking on the basis of the Gini coefficient.

The main factor behind this is that spending on non-cash benefits in Australia was the lowest among these countries as a percentage of disposable income around 19 per cent of disposable income compared to an OECD average of 29 per cent and a high of 41 per cent of disposable income in Sweden.

However, as with spending on cash transfers, spending on non-cash benefits in Australia appears to be very target efficient. The reduction in the Gini coefficient in percentage points per unit of non-cash spending was the fourth highest in the OECD, while the reduction in relative income poverty per unit of spending was the highest in the OECD. Overall, income poverty in Australia was reduced from 15 per cent to 7.9 per cent, the equal fifth largest poverty reduction effort. Overall, this suggests that Australia's welfare state design is more effective in reducing poverty than it is in reducing inequality.

OECD (2011) also found that spending on education benefits in Australia was the lowest in the OECD as a percentage of household disposable income and spending on health care was the equal lowest, and spending on early childhood education and care was the second lowest. The OECD did not have figures on spending on public housing in Australia, and while public housing is tightly targeted to the poor, the low level of benefits (about one quarter of one per cent of average household disposable income and 3.3 per cent for the lowest quintile) is unlikely to change the results at all. However, the OECD also did not have figures for Australia for spending on long-term elderly care services, and these are much more significant. 


\section{The impact of indirect taxes}

Neither OECD (2008) nor OECD (2011) includes the impact of indirect taxes in their measure of incomes. In 2010 taxes on goods and services in Australia amounted to 7.3 per cent of GDP, the fourth lowest level in the OECD, exceeding only Japan, Switzerland and the USA. The OECD average was 11.0 per cent of GDP and the highest level was in Hungary where taxes on goods and services were around 16 per cent of GDP.

The case for taking account of the impact of these taxes has been put by Warren (2008):

... while personal income and social security taxes on employees are a significant proportion of GDP, they are just part of the total tax burden. For many countries high consumption taxes are accompanied by low personal income taxes and vice versa. ... These differences imply that any inter-country comparison of the impact of government taxes on individuals which omits consumption taxes will yield biased results because of both the different level and mix of these taxes. ... The case for including consumption taxes along with personal income tax and employee social security contributions taxes in any inter-temporal or cross-country comparisons of the impact of government tax policies is therefore clear. Even if the contribution and composition of consumption taxes remained similar and unchanged over time and between countries, studies focusing only on personal income tax and employee social security contributions will provide a partial assessment because the incidence of these two groups of taxes is significantly different (2008: 10).

While country studies of the distributional impact of all government taxes have a long history starting from the 1960s (Warren, 2008), international comparisons have been more limited; Warren (2008) identifies three cross-national studies Garfinkel, Rainwater and Smeeding (2006), Harding, Warren and Lloyd (2007) and O'Donoghue, Baldini and Mantovani (2004).

O'Donoghue, Baldini and Mantovani (2004) provide the widest potential base for comparison of consumption taxes in Australia with EU countries. Comparing their results with the most recent ABS study of the Impact of Government Benefits and Taxes shows that the level of indirect taxes on consumption at 10.1 per cent of equivalised household disposable income is lower in Australia than in any of the 12 EU countries they studied, although Luxembourg at 10.3 per cent and the Netherlands at 11.5 per cent are not much higher than Australia. But in half of these EU countries, consumption taxes exceed 15 per cent of equivalised disposable income and in France and Ireland the level of consumption taxes is twice as high as in Australia, at 19.6 per cent and 20.5 per cent, respectively. 
The impact of VAT in these 12 European countries is much greater than the impact of GST in Australia. Precise comparisons are not possible due to the different ways in which results are reported ${ }^{4}$ but in Australia the GST raises 6.6 per cent of equivalised disposable income from the bottom quintile and 3.5 per cent from the richest quintile. In Europe VAT paid by the second decile ranges from a low of 11.9 per cent of disposable income in Luxembourg to more than 23 per cent in Sweden and France; correspondingly the amount collected from the second richest decile ranges between eight and 15 per cent of disposable income. These results suggest that while the regressivity of these consumption taxes is lower than in many European countries, there are EU examples where the distribution is not dissimilar to Australia. For example the ratio of GST collected from the bottom quintile to GST collected from the richest quintile as a percentage of equivalised disposable income in Australia is 1.88 to 1, whereas the corresponding ratios for the poorest decile to the richest decile ranges from 1.4 to 1 in Belgium to 5.6 to 1 in Sweden, with other countries showing ratios of between 2 and 4 to 1 .

O'Donoghue, Baldini and Mantovani (2004) also look separately at the impact of excise duties, which are generally more regressive than VAT. However, excise duties play a much smaller role in countries with high VAT rates, but are more significant in Ireland and the UK. For example, excise duties are equivalent to 6.5 per cent of equivalised disposable income in the United Kingdom and 9.8 per cent in Ireland but range between two and five per cent in other countries in the study, which is comparable to Australian taxes on alcohol, tobacco and motor vehicle fuels of 2.7 per cent of disposable income.

In his own study, Warren (2008) analyses the broad impact of non-cash benefits and indirect taxes in 24 OECD countries around 2000. He finds that in-kind public services generally reduce the Gini index of income inequality, but including consumption taxes partly offsets the positive redistributive effects of in-kind public services. This offset is on average only some nine per cent of the impact of including in-kind services, but as much as 22 per cent for Turkey and 18 per cent for Mexico, Netherlands and Greece and only two per cent in the United States, and three per cent in Australia, Japan and Sweden. Overall, Australia's inequality ranking 'improves', falling from the tenth highest on the basis of cash disposable income to the twelfth highest on cash income plus indirect benefits to the thirteenth highest on final income.

It is worth noting, however, that Warren's estimates of the impact of consumption taxes is based on the distribution of consumption taxes in Australia, adjusted to other countries by the relative ratios of other countries' consumption taxes to GDP relative to Australia in 2002. This is because a truly comprehensive study of

4 Specifically, Australian results are reported for quintiles and EU results for deciles. 
the impact of consumption taxes would require a multi-country team working over many years. It thus abstracts away from differences in consumption patterns across income groups in each country and from differences in the base and rate of different consumption tax regimes. Given that the Australian GST taxes food at a zero rate, for example, while most EU countries tax food at between five and ten per cent, and Denmark at 25 per cent, it is likely that Warren's estimates for EU countries understate their regressive impact.

\section{Employer social security contributions}

A related but even more significant gap in the standard framework is the complete absence of employer social security contributions in standard income distribution analyses. Given that these taxes are paying for a large part of social security spending in some countries, but do not exist in Australia or New Zealand, and are very low in Denmark and relatively low in the remaining English-speaking countries, their absence from welfare state comparisons is particularly problematic (Whiteford, 1995). ${ }^{5}$ For example, using LIS data for the 1980s Whiteford and Kennedy (1994) calculated that the average transfers received by Australian households were just over half the average taxes paid. In France, in contrast, transfers were around 2.75 times the taxes measured as being paid by households - French households were apparently getting nearly two-thirds of their social security system 'for free'! It is employer social security contributions that fill this gap in France, but because they are paid by employers to government they do not pass through households and do not appear in household income surveys.

Employer social security contributions can be considered deferred earnings similar to employer-provided superannuation. For example, the United Nations Provisional Guidelines for Income Statistics (1977) advocated the inclusion of employers' contributions to social security schemes as part of wage and salary income in income surveys. The Canberra Group made a similar recommendation, noting that employer contributions should be counted both as part of market income and as part of taxes. Since 2007 Eurostat has collected information on employer social security contributions as part of the Survey of Income and Living Conditions (EU-SILC). However, while these data are now collected they are not included in the main income aggregates either as part of gross income or taxes paid (Atkinson and Marlier, 2010). Warren (2008) also does not analyse the distributional impact of employer social security contributions, but this is because his remit was to evaluate the impact of consumption taxes.

5 O'Donoghue et al (2004) estimate that employer social security contributions range between three to four per cent of equivalised disposable income in Denmark and Ireland and 6.8 per cent in the United Kingdom to more than 20 per cent in Sweden, France and Belgium. 
The progressivity of employer social security contributions varies across countries; many countries have contribution floors which provide a degree of progressivity, while many also have contribution ceilings which reduce progressivity. ${ }^{6}$ The effect of including employer social security contributions in private income and taxes would be to increase inequality in private incomes, since this approach treats them effectively as part of the wage package, and those who are unemployed, on welfare or retired would not receive this form of income. Moreover, including employer contributions as part of taxes would mean they would have no effect on inequality in disposable incomes, but the degree of redistribution achieved by the welfare state would increase in those countries with these taxes. This would therefore move in the opposite direction to the effect of re-ranking.

It could be argued that the Superannuation Guarantee plays an analogous role in Australia. There are strong arguments for considering employer superannuation contributions, both those under the SG and additional contributions, as being part of the wage package, implying that they should be included in private income. The common practice of advertising salaries as inclusive of superannuation and the origin of compulsory superannuation as a trade-off in national wage cases under the Accord strengthen the case for this view. Moreover those benefiting from higher-than-mandated employer contributions would undoubtedly regard their overall living standards as being reduced if employers reduced superannuation contributions. Superannuation contributions are not paid to government, however, while employer social security contributions are, and superannuation is therefore not part of government welfare state redistribution as conventionally defined, even though it is mandatory.

\section{Assessing the combined effect of non-cash benefits and indirect taxes}

As discussed earlier, ideally to identify the distributional impact of different welfare state arrangements it would be best to make the analysis as comprehensive as possible. Unfortunately, there are no multi-nation comparative studies that allow a more precise measure of the impact of non-cash benefits combined with the impact of indirect taxes. However, it is possible to compare results based on a very similar methodology used by the Office of National Statistics in the United Kingdom and also used by the ABS in Australia.

6 On the other hand, if those below contribution floors are not entitled to benefits, the overall progressivity of the tax-transfer system might be reduced. 
Table 5 shows estimates of the components of final income for different income quintiles in Australia and the United Kingdom in 2009-10 with income components adjusted to Australian dollars using purchasing power parities.

Table 5 Components of final income for income quintiles, Australia and United Kingdom, 2009-10

\begin{tabular}{|l|c|c|c|c|c|c|}
\hline & Bottom & 2nd & 3rd & 4th & Top & $\begin{array}{c}\text { All } \\
\text { households }\end{array}$ \\
\hline Australia & & \multicolumn{7}{|l|}{} \\
\hline Private income & 13817 & 38219 & 69346 & 105166 & 189425 & 84102 \\
\hline Cash benefits & 16841 & 16007 & 8707 & 3598 & 1147 & 9229 \\
\hline Benefits in kind & 23046 & 23046 & 19135 & 15642 & 12461 & 18614 \\
\hline Direct taxes & -782 & -3493 & -8395 & -15798 & -38114 & -13556 \\
\hline Indirect taxes & -5944 & -7195 & -9072 & -11054 & -14339 & -9542 \\
\hline Final income & 46978 & 66635 & 79670 & 97606 & 150580 & 88847 \\
\hline United Kingdom & & & & & \\
\hline Private income & 10882 & 24367 & 51836 & 85174 & 174889 & 69429 \\
\hline Cash benefits & 15453 & 18590 & 13783 & 8866 & 4472 & 12232 \\
\hline Benefits in kind & 16962 & 16282 & 15914 & 13835 & 11502 & 14899 \\
\hline Direct taxes & -2683 & -4939 & -10889 & -18866 & -43781 & -16232 \\
\hline Indirect taxes & -6657 & -7782 & -10011 & -12092 & -16706 & -10649 \\
\hline Final income & 33958 & 46517 & 60633 & 76917 & 130376 & 69681 \\
\hline
\end{tabular}

Source: Calculated from Office for National Statistics, The Effects of Taxes and Benefits on Household Income, 2009/10 and Australian Bureau of Statistics, Government Benefits, Taxes and Household Income, 2009-10. UK values are adjusted by purchasing power parities to Australian dollars with one pound equal to \$2.25.

Private incomes are higher for all income groups in Australia, while on average cash benefits are higher in the United Kingdom except for the lowest income quintile. Benefits in-kind are higher in Australia for all income groups, while direct and indirect taxes are lower in Australia for all income groups, and as a result final incomes are higher in Australia for all income groups. In addition, as could be expected, while the overall average private and final incomes for all households are similar (more so in the UK than in Australia), the effect of redistribution is to increase the incomes of low-income groups and reduce the incomes of high-income groups. For example, the final income of the poorest income quintile in Australia is 3.4 times their private incomes, while for the richest quintile their final incomes are 79.5 per cent of their private incomes; the corresponding figures for the United Kingdom are 3.1 and 74.5 per cent. 
To assess the effects of these different income components on inequality, Table 6 shows an estimate of the distribution of benefits and taxes in each country, the weight of benefits and taxes, and the impact of benefits and taxes on income disparities.

As a starting point, it is worth noting that the two studies suggest that overall income disparities are narrower in Australia than in the United Kingdom, as the Q5 to Q1 ratio for final income is 3.21 in Australia and 3.84 in the United Kingdom. However, the Australian data include imputed income from owneroccupied housing which will have an inequality reducing effect not included in the calculations for the United Kingdom.

Table 6 Impacts of taxes and benefits on income distribution, Australia and United Kingdom, 2009-10

\begin{tabular}{|l|c|c|c|}
\hline & Distribution & Weight & Impact \\
\hline Cash benefits & \multicolumn{4}{|l|}{} \\
\hline Australia & 14.7 & 10.4 & -7.5 \\
\hline United Kingdom & 3.4 & 17.6 & -9.3 \\
\hline Direct taxes & \multicolumn{5}{|l}{} \\
\hline Australia & 48.7 & 15.3 & -1.1 \\
\hline United Kingdom & 16.3 & 23.3 & -1.1 \\
\hline Non-cash benefits & \multicolumn{5}{|l}{} \\
\hline Australia & 1.85 & 21.0 & -2.0 \\
\hline United Kingdom & 1.47 & 21.4 & -3.1 \\
\hline Indirect taxes & \multicolumn{5}{|l|}{} \\
\hline Australia & 2.41 & 10.7 & +0.9 \\
\hline United Kingdom & 2.51 & 15.3 & +1.3 \\
\hline
\end{tabular}

Notes: Distribution is the ratio of the benefits received by the poorest quintile to those received by the richest quintile and the ratio of the taxes paid by the richest quintile to those paid by the poorest quintile, respectively. Weight is the level of benefits and taxes as a percentage of final income. Impact is the difference between the Q5 to Q1 ratio as a result of adding each income component. Households are ranked by equivalised disposable income using the modified OECD equivalence scale. In Australia, noncash benefits are added before indirect taxes are deducted, while in the United Kingdom indirect taxes are deducted first.

Source: Calculated from Office for National Statistics, The Effects of Taxes and Benefits on Household Income, 2009/10 and Australian Bureau of Statistics, Government Benefits, Taxes and Household Income, 2009-10.

The progressivity of cash benefits is greater in Australia than in the United Kingdom, with the poorest quintile of households receiving nearly 15 times as much as the richest quintile, compared to a ratio of 3.4 to 1 in the United Kingdom. However, the overall weight of benefits in the United Kingdom at 
17.5 per cent of final income is greater than in Australia at 10.4 per cent of final income, and this greater weight means that the UK benefit system actually reduces income disparities by more than the Australian benefit system.

Similarly, even though the direct tax system is more progressive in Australia than in the United Kingdom, the greater volume of taxes in the UK means that the two systems reduce disparities to a very similar degree. Comparisons of the impact of non-cash benefits are complicated by the fact that the approach used varies between countries, with the ABS adding non-cash benefits to disposable income before deducting indirect taxes, while the ONS in the UK deducts indirect taxes before adding non-cash benefits. This difference in ordering does not affect either the progressivity of these benefits or taxes and their weight but will have an effect on their measured impact, since the starting point differs between countries. However, these figures suggest that non-cash benefits reduce inequality to a somewhat greater extent in the UK than Australia, but that indirect taxes have a stronger effect in the UK in widening disparities. It is also worth noting that in both countries indirect taxes appear to increase disparities by about as much as direct taxes reduce disparities, but as noted above taxes are necessary to pay for the spending which appears most effective in reducing inequality.

\section{Taking account of wealth and imputed income from owner-occupied housing}

It has long been recognised that a significant feature of economic wellbeing in Australia is its relatively high level of home ownership (Castles, 1997), which has led to a relatively high level of personal wealth. Indeed, according to the 2012 Credit Suisse Global Wealth Report, Australian wealth per adult in 2012, at USD 355,000, was the second highest in the world - after Switzerland and ahead of Norway. Its median wealth of USD 194,000 is the highest in the world. The composition of wealth is heavily skewed towards real assets, which form 64 per cent of the total. The level of real assets per adult in Australia is now the second highest in the world after Norway, in part reflecting high house prices. Compared to the rest of the world, very few Australians have a net worth that is less than US\$10,000. This reflects factors such as relatively low credit card and student loan debt. The proportion of those with wealth above USD 100,000 is the highest of any country - eight times the world average. With 1,571,000 people in the top one per cent of global wealth holders, Australia accounts for 3.4 per cent of this group, despite having just 0.4 per cent of the world's adult population.

The fact that median Australian wealth is the highest in the world contributes to the fact that by international standards Australia also appears to have one of 
the least skewed distributions of net worth in the developed world. Figure 9 shows a simple measure of 'skewedness' - the ratio of mean net worth to median net worth.

Apart from Italy, Australia has the lowest ratio of mean to median net worth in these countries; it is notable that the Scandinavian countries and Switzerland have the most skewed wealth distributions. A recent study by the European Central Bank (2013) found that Germany and Austria have distributions of net worth that fall between the levels shown for France and Norway, while Cyprus, Spain and Greece have distributions that are similar to Italy. While a number of Southern European countries appear to have less unequal wealth distributions than Australia, the much greater level of net worth in Australia could be expected to have a stronger equalising effect.

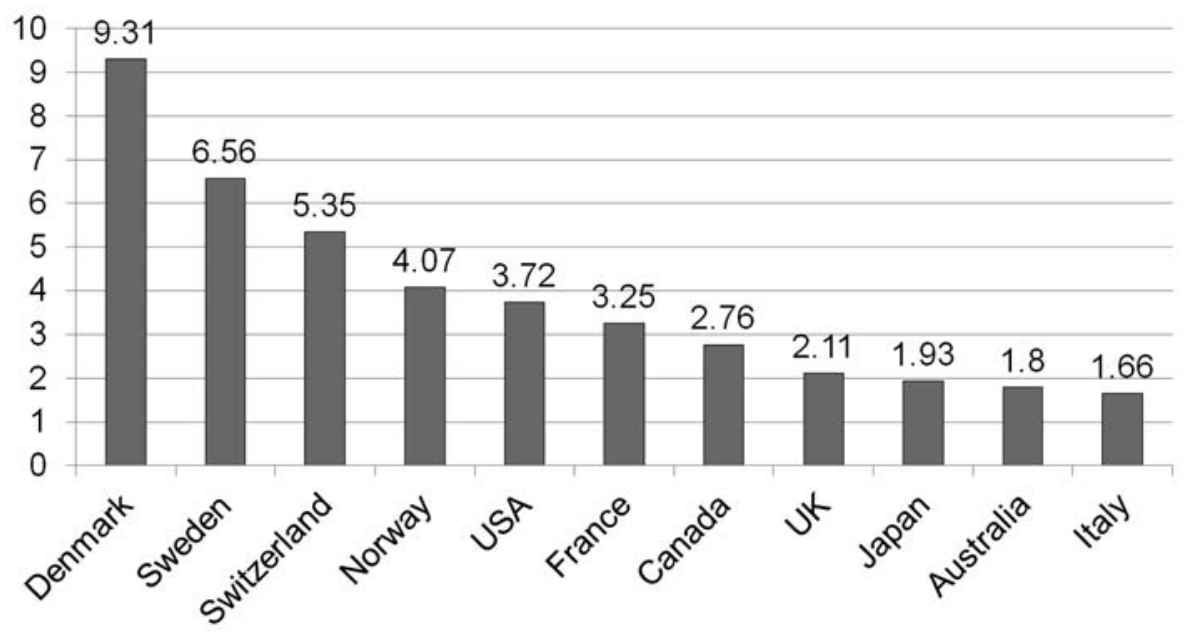

Figure 9 Australia's wealth distribution is one of the least skewed in the OECD. Ratio of mean to median net worth, 2011

Source: Calculated from Credit Suisse, 2012.

The ABS has undertaken surveys of net worth in Australia since 2003-04, and it is their figures that are used in the Credit Suisse (2012) report. The level of inequality in net worth is strongly influenced by the measure by which net worth is ranked. When households are ranked by net worth, wealth is much more unequally distributed than disposable income, and net worth has become much more unequally distributed than income - the Q5 to Q1 ratio increasing from around 42 to 1 in 2003-04 to 62 to 1 in 2009-10.

A very different picture appears, however, when households are ranked by their disposable income - that is when the joint distribution of net worth and income is considered. Overall, when households are ranked by disposable income the 
Q5 to Q1 ratio for net worth is around 3.2 to 1 ; that is net worth is less unequally distributed than disposable income. The main reason for this is that owneroccupied housing accounts for about half of all net worth, and the Q5 to Q1 ratio for housing is only around 2 to 1 . Other non-financial assets (e.g. vehicles and dwelling contents) are even less unequally distributed. Total liabilities tend to fall most heavily on the richest quintile. This pattern reflects the life-cycle accumulation of assets, so that older people tend to own their homes outright, while younger and higher-income groups are still acquiring assets and thus have more substantial debts.

While the distribution of net worth ranked by disposable income is less unequal than the distribution of disposable income, there is evidence of growing inequality in its impact since 2003-04. Figure 10 shows that disparities in net worth have widened somewhat, even though disparities in owner-occupied dwelling wealth narrowed slightly. Two factors seem important - an increase in disparities of financial assets held by different income groups and reduced disparities in liabilities, which therefore reduce the net worth of higher-income groups less than in the past.

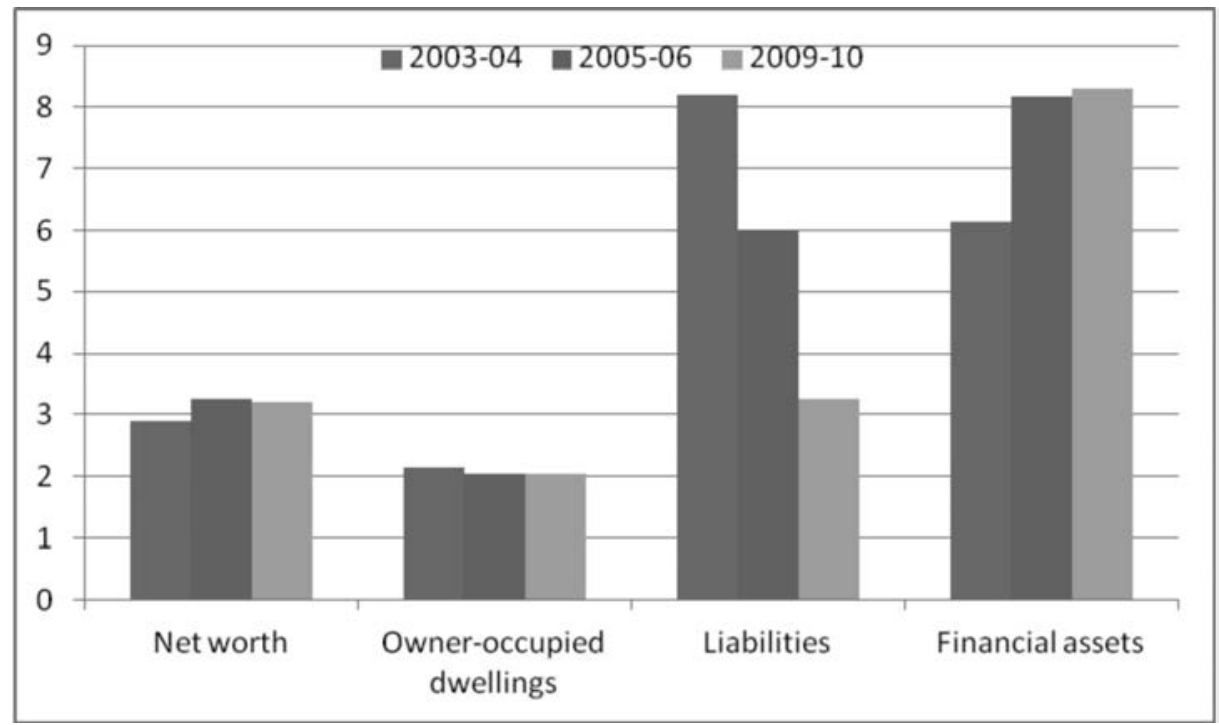

Figure 10 Trends in distribution of household net worth, Australia, 2003-04 to 2009-10. 05/01

Source: Calculated from ABS, Household Wealth and Wealth Distribution, Australia, various years.

Following the recommendation of the Canberra Group, Eurostat has collected information necessary to calculate the benefits of imputed rent since 2007. Imputed rent has been added for all households that do not report that they 
pay full rent, either because they are owner-occupiers or because they live in accommodation rented at a lower price than the market price, or because the accommodation is provided rent-free. However, Eurostat note that the inclusion of imputed rent in the standard EU-SILC income concept would have a significant impact on all income-based indicators and would create a serious break in the time series as imputed rent could not be included in the indicators prior to 2007 due to the unavailability of the required data.

Chapter 7 of Atkinson and Marlier (2010) presents estimates of the distributional impact of moving from measures of disposable income to incomes augmented with imputed rents for 25 European countries in 2007. In the Netherlands and Norway, adding imputed rent actually increases the Gini coefficient, while in France it has no effect; in the remaining countries, the distributional impact ranges from negligible to a reduction in the Gini coefficient of up to 0.036 Gini points, with the impact being largest in the United Kingdom, followed by Estonia and Spain. Imputed rent also raises average incomes in most countries, again with the exception of the Netherlands and Norway, with the increase in average incomes being highest in Hungary at around 23 per cent.

The ABS has also included estimates of imputed rent in a number of its income surveys, with the most recent estimates being for 2009-10. In 2009-10, imputed rent is estimated to raise average household incomes from $\$ 848$ per week to $\$ 905$ per week, an increase of 6.7 per cent overall. For owners without a mortgage the increase in average income was around 20 per cent, while for those renting from state or territory housing authorities the increase was 17 per cent.

In 2009-10, the addition of imputed rent to equivalised household disposable income in Australia was estimated to reduce the Gini coefficient from 0.328 to 0.309 , a reduction of 0.019 Gini points. This reduction in inequality was exceeded in nine of the 25 countries of Europe in the Atkinson and Marlier report (2010), while the increase in mean income was lower than in all but seven European countries. The apparently surprising result that imputed rent has a relatively minor impact on mean income in Australia reflects the fact that imputed rents in both the ABS and Eurostat studies not only includes imputed rent from owneroccupied housing, but also includes the value of public housing subsidies, which are much more significant in a large number of European countries. For example, in 2009-10 only 3.9 per cent of Australian households were public renters, with a further five per cent paying reduced rents or living rent-free. In contrast nearly 18 per cent of the UK population lived in households not paying market rents and nearly one quarter in Hungary, with nine other European countries having higher shares of reduced rent tenants than Australia. It is likely to be this factor that explains Australia's relatively low ranking in the contribution to average incomes despite its very high level of housing wealth. However, it is also important to bear in mind that this stronger equalising effect 
of public housing in many European countries was already included in estimates of the impact of government non-cash benefits on income distribution, so that the further addition of imputed income from owner-occupied housing would be likely to have a stronger effect in Australia than is suggested by these figures.

\section{Conclusions}

Broadening the measure of resources has important implications for assessments of the impact of the welfare state on income levels and on inequality, as well as having implications for understanding the effectiveness of Australia's welfare state compared to those in other developed countries.

To sum up, measures of the effectiveness of welfare state redistribution are biased due to the counterfactual underlying any such evaluation - that the welfare state has not affected the distribution of private income and that the differences in welfare state design across countries have had the same zero effect on private incomes. Given that the counterfactual is by definition unobservable, the most that can be said is that when households are ranked by their 'endpoint' rather than by their starting point, the degree of redistribution achieved by the welfare state in many countries is significantly less than is conventionally measured. This is not the case to the same extent in Australia (or other Englishspeaking countries), which implies that the degree of redistribution achieved in Australia is higher than conventionally estimated. Having said this, this specific effect does not alter the level of inequality in disposable incomes: Australia is more effective than conventionally measured, but no less unequal in outcomes.

On the other hand, taking account of non-cash benefits raises living standards across the income distribution and reduces inequality. The reduction in the inter-quintile ratio in Australia appears to be close to the OECD average, but the reduction in the Gini coefficient is less than the OECD average; the result is that when measured by the Gini coefficient Australia's inequality ranking worsens somewhat. This may be due to an incomplete accounting, as neither public housing nor nursing home care are included in the data for Australia used in the OECD comparative studies. Inclusion of public housing, however, is unlikely to have a large impact in Australia, due to the low share of households in this tenure.

Taking account of indirect taxes on consumption is likely to improve Australia's relative ranking in terms of inequality, both because the weight of indirect taxes is lower and because the structure of indirect taxes appears likely to be less regressive than in many European countries. The size of this effect is unclear, however, as cross national studies of the impact of indirect taxes are not common. 
Adding imputed income from owner-occupied housing also raises household incomes and reduces inequality in living standards, and seems likely to improve Australia's international ranking. Again, the available evidence on this is not definitive because existing studies simultaneously take account of both the benefits of imputed income from owner-occupied housing and the benefits of government-subsidised public housing. As noted above, because public housing is less prevalent in Australia it is plausible that owner-occupied housing provides a larger share of the redistributive effect here. In addition, existing comparative studies of the impact of non-cash benefits also include the impact of public housing, so it would be important to avoid double counting its impact on the level of inequality across countries

Finally, the effects of employer social security contributions and employer provided private fringe benefits need to be considered. If they are added to private income and then not counted in disposable income, then the effect would be to increase the extent of redistribution but not alter the extent of disposable income inequality. However, in the case of employer contributions to private pensions it can be argued that they should be counted in a comprehensive measure of resources, since they are an addition to net worth. Similarly, the earnings of superannuation and private pension funds also increase net worth, although earnings can be negative as well as positive.

An important point that comes out in this review is that the Australian welfare state is likely to be relatively more effective in reducing income poverty than it is in reducing income inequality as measured by the Gini coefficient. This is not surprising given that the design of the Australian welfare state emphasises targeting and therefore poverty alleviation. Given that cash transfers in Australia are more targeted to the lower half of the income distribution than in any other OECD country, it is unsurprising that the Gini coefficient - which is well known to be sensitive to changes in income in the middle of the distribution - should be reduced less in Australia. Whether this is problematic or not depends on values about the objectives of the welfare state.

Overall, broadening the definition of income to take account of the factors discussed here shows higher living standards and lower inequality and relative poverty in most countries, and it also narrows the difference between measured outcomes in different countries. However, despite the work of the Canberra Group and national and international statistical agencies in significantly improving the comprehensiveness of household income surveys, questions remain about the methodology of comparative analysis of welfare state outcomes. 


\section{References}

Adema, W and Ladaique, M (2005). Net social expenditure, Labour market and social policy occasional paper, OECD, Paris.

-and Whiteford, P (2010). 'Public and private social welfare', in Oxford handbook of comparative social policy, ch. 8, Oxford University Press.

Atkinson, A and E Marlier (eds), (2010). Income and Living Conditions in Europe, Eurostat, Brussels. http://epp.eurostat.ec.europa.eu/cache/ITY_ OFFPUB/KS-31-10-555/EN/KS-31-10-555-EN.PDF

Australian Bureau of Statistics, (various years), The Effects of Government Benefits and Taxes on Household Income, ABS Catalogue No. 6537.0, Canberra.

- (various years), Household Wealth and Wealth Distribution, Australia, Catalogue No. 6554.0, Canberra.

Barr, N (1992). 'Economic theory and the welfare state: a survey and reinterpretation', Journal of Economic Literature, vol. 30, June.

(1999). 'Fundamentals of social security analysis', Australian Social Policy, 1999/1: 7-29.

(2001). The welfare state as piggy bank: information, risk, uncertainty, and the role of the state, Oxford University Press, Oxford.

The Canberra Group (2001). Expert Group on Household Income Statistics: Final Report and Recommendations. Ottawa.

(2011) Canberra Group Handbook on Household Income Statistics, Second Edition, United Nations Economic Commission for Europe, Geneva.

Castles, F (1997). 'The Institutional Design of the Australian Welfare State'. International Social Security Review, 50 (2): 25-41.

Castles, I (1987). 'The effects of government benefits and taxes on household incomes: Estimates for Australia and other countries'.

Credit Suisse (2012). Global Wealth Report, Credit Suisse, Zurich.

Daley, J (2013). Budget pressures on AustralianGovernments, Grattan Institute, Melbourne.

Esping-Andersen, G (1990). The three worlds of welfare capitalism, Polity Press, Cambridge. 
Garfinkel, I, L Rainwater, and TM Smeeding (2006). 'A Re-examination of Welfare State and Inequality in Rich Nations: How In-Kind Transfers and Indirect Taxes Change the Story'. Journal of Policy Analysis and Management 25(4): 855-919.

Greenville, J, Pobke, C and Rogers, N (2013). Trends in the Distribution of Income in Australia, Productivity Commission Staff Working Paper, Canberra.

Gruen, FH (1989). Australia's Welfare State - Rearguard or Avant Garde? Discussion Paper No. 212, Centre for Economic Policy Research, Australian National University.

Harding, A, Warren, N, and Lloyd R (2007). 'Beyond conventional measures of income: including indirect benefits and taxes', in The Distributional Effects of Government Spending and Taxation (ABA festschrift for Tony Atkinson) edited by Micklewright J and Jenkins. T., (OUP:Oxford), pp84-102

Korpi, W and Palme, J (1998). 'The paradox of redistribution and the strategy of equality: welfare state institutions, inequality and poverty in the Western countries', American Sociological Review, vol. 63, no. 5.

Layard, R (1977). 'On measuring the redistribution of lifetime income', in MS Feldstein and RP Inman (eds), The economics of public services, Macmillan, London.

Mitchell, D, Harding, A and Gruen, F (1994). 'Targeting Welfare', Economic Record, 70, 10: 315-340.

O'Donoghue, C Baldini, M and Mantovani, D (2004). 'Modelling the redistributive impact of indirecttaxes in Europe: an application of EUROMOD', EUROMOD Working Papers EM7/01, EUROMOD at the Institute for Social and Economic Research.

Office for National Statistics, (2011). The Effects of Taxes and Benefits on Household Income, 2009/10, Newport.

Organisation for Economic Co-operation and Development (OECD) (2008). Growing unequal: income distribution and poverty in OECD countries, OECD, Paris.

Organisation for Economic Co-operation and Development (OECD) (2011). Divided we stand: Why inequality keeps rising, OECD, Paris.

Pederson, AW (1994). The welfare state: still no answer to the big questions? LIS working paper, CEPS/INSTEAD, Luxembourg.

Rawdanowicz, L, E Wurzel and A Christensen (2013). 'The Equity Implications of Fiscal Consolidation', OECD Economics Department Working Papers, No. 1013, OECD Publishing. doi: 10.1787/5k4dlvx2wjq0-en 
Reynolds, M and Smolensky, E (1977). Public expenditures, taxes and the redistribution of income: the USA, 1950, 1961, 1970, Academic Press, New York.

Ringen, S (1987). The possibility of politics, Clarendon Press, Oxford.

Saunders, P (ed) (1987). Redistribution and the welfare state: estimating the effects of government benefits and taxes on household income, proceedings of a workshop held at the University of New South Wales, 13 May 1987, reports and proceedings, no. 67, Social Welfare Research Centre, University of New South Wales.

Saunders, P (1994). Welfare and Inequality, Cambridge University Press, Melbourne.

Smeeding, T, Saunders, P, Coder, J, Jenkins, S, Fritzell, J Hagenaars, A, Hauser, $\mathrm{R}$, and Wolfson, M (1992). Noncash Income, Living Standards and Inequality: Evidence from the Luxembourg Income Study, LIS Working Paper, CEPS/ INSTEAD, Luxembourg.

United Nations (1977). Provisional Guidelines on Statistics of the Distribution of Income, Consumption and Accumulation of Households, New York.

Warren, N (2008). A review of studies on the distributional impact of consumption taxes in OECD countries, OECD social, employment and migration working paper, OECD, Paris.

Werding, M (2003). 'After another decade of reform: do pension systems in Europe converge?', CESifo DICE Report, vol. 1/2003.

Whiteford, P (1995). 'The Use of Replacement Rates in International Comparisons of Benefit Systems', International Social Security Review, 48, 2/95, 3-30.

— (1997). 'Targeting welfare: a comment', Economic Record, vol. 73, no. 220, March: 45-50.

(1998). 'Is Australia particularly unequal?', in P Smyth and B Cass (eds), Contesting the Australian way: states, markets and civil society, Cambridge University Press, Melbourne.

- (2010). 'The Australian tax-transfer system: architecture and outcomes,' Economic Record, 86 (275), 528-544.

Whiteford, P and Kennedy, S (1995). Incomes and Living Standards of Older People: A Comparative Analysis, UK Department of Social Security, Research Report No. 34, HMSO, London. 